\title{
CENOZOIC AMPULLINIDAE AND NATICIDAE (MOLLUSCA, GASTROPODA) FROM PATAGONIA, ARGENTINA
}

\author{
MIGUEL GRIFFIN ${ }^{1}$ AND GUIDO PASTORINO ${ }^{2}$ \\ ${ }^{1}$ Facultad de Ciencias Naturales y Museo, Universidad Nacional de La Plata, Paseo del Bosque s/n, B1900FWA La Plata, Argentina, \\ $<$ miguelgriffin@aol.com>; and ${ }^{2}$ Museo Argentino de Ciencias Naturales "Bernardino Rivadavia," Av. Angel Gallardo 470 $3^{\circ}$ piso lab 57, \\ C1405DJR Ciudad Autónoma de Buenos Aires, Argentina, <gpastorino@macn.gov.ar>
}

\begin{abstract}
A revision of the Cenozoic Ampullinidae and Naticidae from a wide range of localities and stratigraphic units in Patagonia revealed the occurrence there of thirteen species referable to these families. Ampullinid species described are Tejonia? tapia (Feruglio, 1935); Tejonia arroyoensis n. sp. and Pseudamaura dubia (Petersen, 1946). Naticids are represented by the following valid species: "Natica" entreriana Borchert, 1901; Euspira patagonica (Philippi, 1845); Notocochlis borrelloi (Brunet, 1995); Bulbus subtenuis (Ihering, 1897); Polinices santacruzensis Ihering, 1907; Polinices puntarenasensis Ihering, 1907; "Polinices" ortmanni Ihering, 1907 (nomen dubium); Polinices mina n. sp.; Glossaulax secundum (Rochebrune and Mabille, 1885); and Darwinices claudiae n. gen. n. sp.
\end{abstract}

\section{INTRODUCTION}

$\mathrm{T}^{\mathrm{s}}$ HE FAMILY Naticidae is a large group of marine gastropods with a worldwide distribution known to occur in rocks of diverse age since the late Mesozoic. Species of this family are characterized by their relatively simple shells, with few characters distinguishing them. Therefore, the taxonomic status of many naticid taxa remains unclear-despite their important role in marine ecosystems - as they generally feed on other molluscs, either bivalves or other gastropods, and their activity as bioeroders can significantly alter the structure of their community.

Twelve extant species are known from the Atlantic coast of southern South America (Pastorino, 2005), and at least 25 nominal species have been introduced for fossil specimens from an array of Cenozoic marine outcrops at many localities in that region, mainly in Argentina. These fossil species have received little attention ever since they were first described. Nevertheless, they have appeared in faunal lists and been used extensively for biostratigraphic frameworks and paleoecological studies. In no case were the specific features of the shell taken into account in order to understand the variability and correct taxonomic identification of the species, a fact severely limiting their usefulness in those analyses. The complicated taxonomic history of the species has subsumed them in confusion, thus relegating them - as also many other taxa of Cenozoic molluscs from Patagonia - to a subordinate role in studying the faunas of that age. This is a hindrance, given their abundance and importance in the trophic chain of benthic faunas. A clear and realistic taxonomic arrangement is a prerequisite to further studies and its importance cannot be overstressed, given the need for a paleobiological approach to the study of this group.

This study aims to clarify the taxonomic placement of the previously known species, by providing detailed information on their stratigraphic and geographic distribution, based on a better resolved stratigraphy of the Patagonian Cenozoic. Delimiting the fossil species of Naticidae and distinguishing lineages are made difficult because of the fragmentary nature of the fossil record and the rather simple and uniform shell characters observed in the extant species. This makes it necessary to consider the different variants of a continuous morphological spectrum appearing at the same locality and roughly the same stratigraphic unit.

Not related to the Naticidae but instead belonging in the Campaniloidea (Bouchet and Rocroi, 2005; Beu and Marshal, 2011) the Ampullinidae Cossmann, 1919, are represented in Paleocene and Eocene rocks in southern South America alongside naticid species. Because they have often been mistaken for naticids, we have included them in this revision. They can be distinguished from naticids by their higher spire and slightly shouldered last whorl, with a somewhat tabulate profile.

\section{GEOLOGIC BACKGROUND}

The ten species of naticids and three of ampullinids described herein come from outcrops that range in age from Danian (early Paleocene) to ?Pliocene (and possibly Pleistocene) and are exposed at diverse localities in central and southern Argentina (Figs. 1-4). The lithostratigraphic units that yielded the specimens also contain other molluscs, mainly oysters, pectinids, and epitoniid and muricid gastropods, all of which have calcitic shells. In some instances, aragonitic shells are preserved as calcite replacements, allowing a fairly detailed description of shell morphology. In most cases, the aragonite has been completely dissolved, rendering the preserved fossils almost unidentifiable. This is the case for many specimens that may belong in the Naticidae or Ampullinidae, but of which nothing can be said about their shell characters beyond a "general naticoid appearance." In such cases we have not used the material until specimens suitable for description are eventually collected. In this section we present a brief account of the stratigraphic units bearing the material used in this paper.

The earliest species of unquestionable Cenozoic Naticidae in the region appear in Paleocene units exposed in several areas across southern Argentina. The best is the Salamanca Formation - a southern equivalent of the Roca Formation - exposed at several localities in Chubut and Santa Cruz. The fossil content of this unit is as yet poorly known, although molluscs coming from it have been described since the early 1900s. Some of the species from the Salamanca Formation were described by Ihering (1907, 1914), Feruglio (1935, 1937) and Petersen (1946). Oil drillings also have provided some of specimens from this unit, and these were described by Feruglio (1935); however, in many cases the material is very poor and collection 


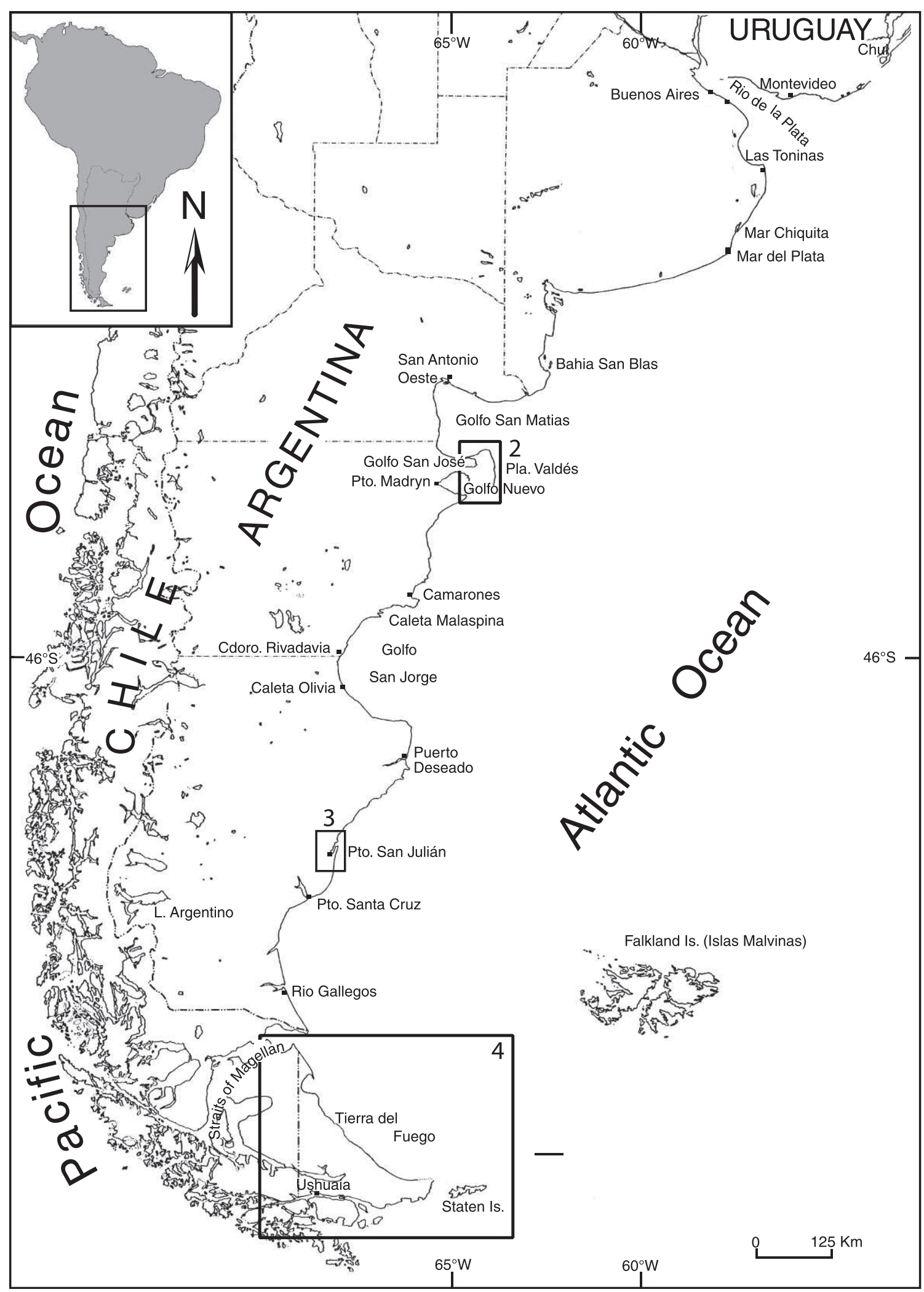

Figure 1 - General map with the sampled localities mentioned in the text. Boxed areas show Valdes Peninsula, Puerto San Julián, and Tierra del Fuego areas mentioned in the text and shown in Figures 2-4.

of additional material is virtually impossible. Probable ampullinids have been described (as naticids) from rocks as old as Jurassic, in northern Patagonia (Manceñido and Damborenea, 1984), but the material has not been revised and younger records of gastropod occurrences are sparse and do not include taxa that may be identified as belonging in this group.

The other Paleocene unit yielding naticids and ampullinids is the Cerro Dorotea Formation, exposed at the south-western 


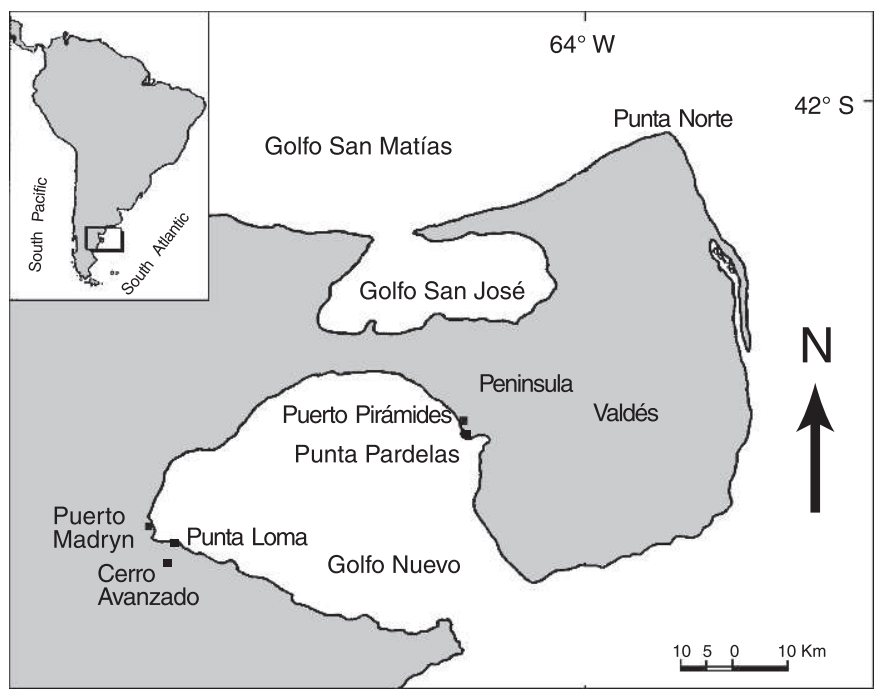

FIgURE 2-Valdes Peninsula area showing localities mentioned in the text.

corner of Santa Cruz Province, adjacent to the border with Chile (Brandmayr, 1945; Hünicken, 1955). This is a richly fossiliferous unit that includes two marine sections separated by continental plant-bearing layers. Shell beds at the top of the section have a diverse fauna of molluscs, most of them with aragonitic shells preserved within cemented calcareous sandstone.

Restricted exposures of marine Eocene rocks are also known from scattered areas in southern Patagonia. Among these, the only one from which naticids have been recovered is the Arroyo Verde Formation (Malvicini and Llambías, 1974), in northeastern Chubut (Rossi de Garcia, and Levy, 1977). Only a few specimens belonging in a new species of ampullinid are known and described herein. Affinities of this taxon remain unclear. Those described from Paleocene rocks are clearly different and belong in a separate genus.

Naticids appear in the San Julián Formation, a unit exposed along the coast between Playa La Mina and just south of San Julián, and inland along the cliffs surrounding the Gran Bajo de San Julián. This formation was formally described by Bertels $(1970,1977)$, although it has been known since the nineteenth century as a richly fossiliferous unit. Darwin (1846) collected part of his material (described by G.B. Sowerby I) from it and Ameghino (1898) based his "Juliense" on the mollusc fauna contained in it; Ortmann (1902) also described material from this locality. Other authors (Camacho, 1967, 1974; Di Paola and Marchese, 1973; Manassero et al., 1997, among others) discussed different aspects of its geology. The age of the San Julián Formation is believed to be Eocene-Oligocene (Bertels, 1975), Oligocene (Náñez, 1988), or more precisely late Oligocene (Barreda, 1997e). The Gran Bajo Member was proposed by Bertels (1977) for the lower part of the section, comprising $23 \mathrm{~m}$ of dark reddish fine sandstones and siltstones exposed at the type locality, i.e., Gran Bajo de San Julián. Overlying this unit are $45 \mathrm{~m}$ of yellowish and brown-greenish medium to coarse-grained sandstones and biogenic limestone very rich in calcitic skeletal remains of invertebrates that Bertels (1977) designated as the Meseta Chica Member.

Geographically more widespread than the San Julián Formation, the Monte León Formation was also formally introduced by Bertels (1970). Its main lithological components are yellowish to grey tuffaceous fine sandstone and siltstone with a variable content of pyroclastic material. It lies exposed along the coast of

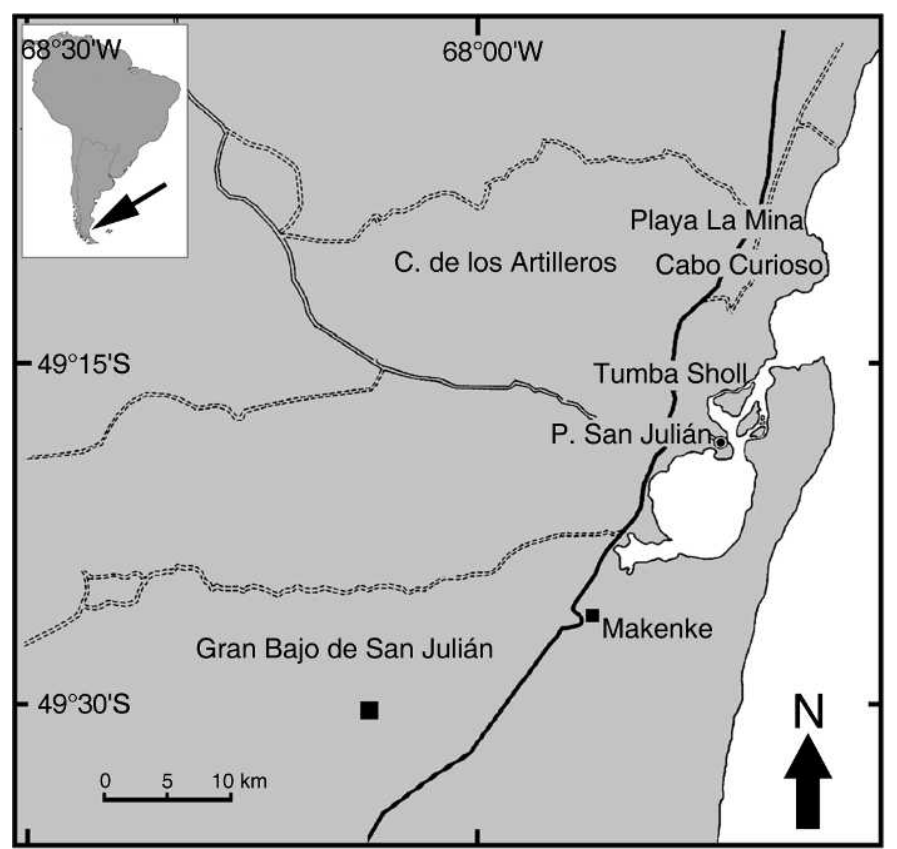

FIgURE 3-Puerto San Julián area showing localities mentioned in the text.

Santa Cruz south of Puerto Deseado and its equivalents probably reach as far north as Trelew, and inland up to the foothills of the Andes. This unit contains a very rich mollusc fauna, representing a large proportion of the named species from the Patagonian Cenozoic, especially in the area near the mouth of the Santa Cruz River, where aragonitic shells are unusually well preserved. The age of the Monte León Formation is generally considered to be late Oligocene to early Miocene (Bertels, 1980; Náñez, 1988; Legarreta and Uliana, 1994; del Río and Camacho, 1998). More recently Barreda and Palamarczuk (2000) considered that the Monte León Formation should be restricted to the early Miocene on the basis of its palynomorph content, an age we agree with herein. Bertels (1980) divided this unit into two members: the Punta Entrada Member (lower) and the Monte Observación Member (upper).

The El Chacay Formation (Chiesa et al., 1995) is probably equivalent (at least in part) to the Monte León Formation and is exposed in northwestern Santa Cruz in the vicinity of Lakes Posadas and Belgrano. This unit includes about $300 \mathrm{~m}$ of richly fossiliferous sandstone and tuffaceous sandstone, which were noted and collected by Hatcher (1897) with the marine invertebrates he collected described by Ortmann (1902). Riggi (1957) surveyed the area and Chiesa et al. (1995) proposed the formal name. Previously, the beds had been included in the Centinela Formation (Furque and Camacho, 1972), the type section of which is located south of Lake Argentino. The age of this formation has been considered from Eocene to Miocene (Ortmann, 1902; Ihering, 1907; Feruglio, 1949; Chiesa and Camacho, 1995; Casadío et al., 2000, 2001). An early Miocene age appears to be favored presently. Equivalent horizons exposed across the border in Chile (referred to the Guadal Formation) have a similar fauna and are considered to be late Oligocene-early Miocene (Niemeyer et al., 1984; Frassinetti and Covacevich, 1999).

The Chenque Formation (Bellosi, 1990) is exposed in the area surrounding Comodoro Rivadavia and probably along the southern coast of the San Jorge Gulf. Based on palynomorphs and dinoflagellates, Barreda (1996, 1997a, 1997b, 1997c, 


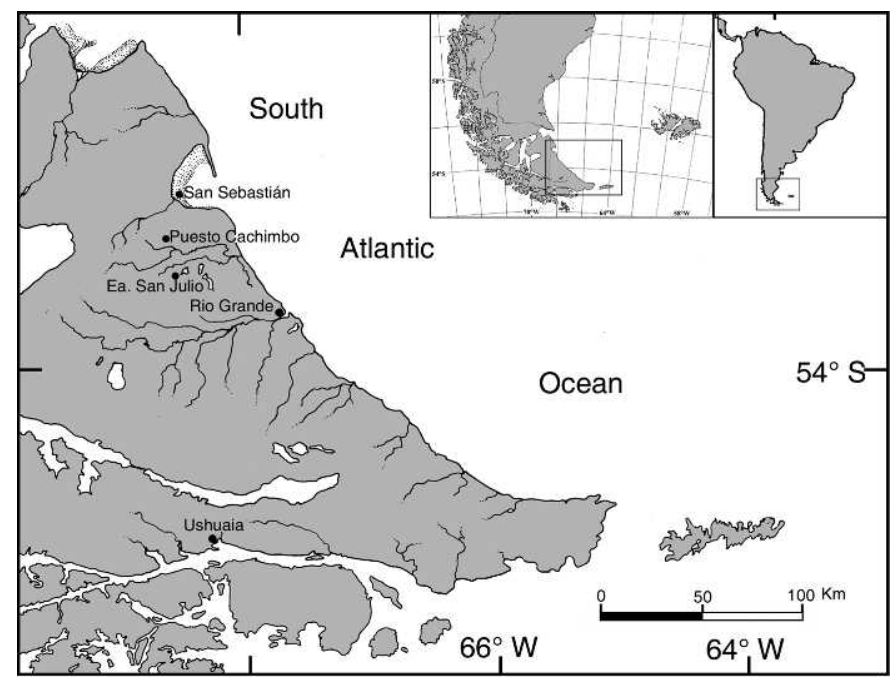

FIgURE 4-Tierra del Fuego area showing localities mentioned in the text.

1997d) suggested a late Oligocene-early Miocene age for it. It is probably a northern equivalent of the Monte León Formation.

Scattered over the northern half of the island of Tierra del Fuego (Estancia San Julio, Puesto El Cachimbo, and San Sebastián) is the Carmen Silva Formation (Codignotto and Malumián, 1981). This unit includes coarse conglomerates, sandstones and siltstones, all of which carry a variably rich fauna of molluscs, among other invertebrates. The section exposed at Estancia San Julio yielded the most diverse and abundant fauna and, despite the conglomeratic nature of the rock, the specimens contained in it are the best preserved, some of them even retaining the original color pattern. The age of the Carmen Silva Formation has been determined to be middle Miocene by Olivero and Malumián (2008).

In the vicinity of Puerto Madryn, in the province of Chubut, the Puerto Madryn Formation (Haller, 1978) has a rich fauna of molluscs, known since Darwin collected material there. This stratigraphic unit overlies the marine early Miocene Gaiman Formation and comprises about $100 \mathrm{~m}$ of interbedded yellowish sandstones, tuff, pebbly sandstones, richly fossiliferous shelly sandstones, and muddy or sandy shell beds (Haller, 1978; del Río, 1992). Fossils from this unit have been described by many different authors, most notably Ihering (1907), del Río (1992, 1994), Brunet (1995, 1997) and Griffin and Pastorino (2006). Del Río (1990a, 1990b, 1991) proposed a middle Miocene age for the Puerto Madryn Formation based on the mollusc assemblages, whereas Scasso et al. (1999), using isotopic data, indicated an earliest late Miocene (middle Tortonian) age for the unit in Península Valdés.

Just northwest of Puerto Madryn lie exposed rocks included in the Bajo el Gualicho Formation, which are in part equivalent to the Monte León and Puerto Madryn Formation (Haller, 1978, 1982). Naticids from this unit (Reichler, 2010) can be easily identified with species common in either of those formations.

When delimiting the fossil species of Naticidae it usually becomes very difficult - because of the fragmentary nature of the fossil record and the rather simple and uniform shell characters observed in the extant species - to distinguish lineages and properly identify the intervening taxa. Therefore, we have carefully considered the different variants of a continuous morphological spectrum appearing at the same locality and roughly the same stratigraphic unit before taking any decision on its taxonomic status.

\section{SYSTEMATIC PALEONTOLOGY}

We used material housed in museum collections as well as specimens collected by us over the years. Among the museum collections revised are: Museo Argentino de Ciencias Naturales "Bernardino Rivadavia" (Buenos Aires, MACN-Pi); Museo de La Plata (La Plata, MLP); Museo Paleontológico "Egidio Feruglio" (Trelew, Chubut, MPEF-PI); Facultad de Ciencias Exactas y Naturales, Universidad de La Pampa (Santa Rosa, GHUNPam); Facultad de Ciencias Exactas y Naturales, Universidad de Buenos Aires (Buenos Aires, CPBA); Facultad de Ciencias Exactas, Físicas y Naturales, Universidad de Córdoba (Córdoba, COR-PZ), Argentina; The Natural History Museum (London, NHMUK), United Kingdom, and Museu de Zoologia da Universidade de São Paulo (São Paulo, MZUSP), Brazil.

Family Ampullinidae Cossmann and Peyrot, 1919

Remarks.-This family includes gastropods that in a way resemble naticids and thus have frequently been mistaken as such. The key characters used by Kase and Ishikawa (2003) to separate the Naticidae from the Ampullinidae (=Ampullospiridae) are the shouldered whorls, tabulate last whorl, and the presence of a sheath, which sometimes may be covered by the inner lip. Protoconchs are also different, i.e., small, smooth and helicoidally coiled in Ampullinidae; almost planispirally coiled and often spirally ornamented with granules in Naticidae. However, wellpreserved protoconchs are rare and only one of the specimens we examined among the material of southern South American Cenozoic Ampullinids and Naticids had one.

Genus Tejonia Hanna and Hertlein, 1943

Type species. - Natica alveata Conrad, 1855, non Troschel, 1852; original designation (=Amaurellina moragai Stewart, 1927); Eocene of California, U.S.A.

This material can not be easily allocated to any of the other ampullinid genera described from Paleogene rocks in North America (Marincovich, 1977), but it shows a remarkable similarity to Tejonia moragai (Stewart, 1927), the type species of Tejonia, a species common in Eocene rocks from the Pacific coast of North America. Tejonia is characterized by shells that may be smooth or carrying very fine non-punctate spiral sculpture. They also have a tabulate last whorl and the shoulder, while narrow, is conspicuous. Spires are commonly high, and a weak cord runs into the umbilicus from the anterior inner lip. These key characters are present in the Patagonian species too, although in some instances not quite as well-developed as in the type species, i.e., the Patagonian taxa have narrower and less conspicuous shoulders than the type species, and the shell appears to be completely smooth in all cases, although preservation is not optimal.

The presence of this genus in southern South America may seem difficult to explain. Nevertheless, other Eocene molluscs known from the area also have a similar distribution, i.e., Venericardia, Periploma (Aelga), Yoldia (Calorhadia), surely related to the land-bridges and seaways that were active at that time (Griffin, 1991).

\section{Tejonia? tapiae (Feruglio, 1935)}

1935 Natica tapiae n. f., Feruglio, p. 45, pl. 4, fig. 4.

1937 Natica tapiae n. f., Feruglio, p. 262, pl. 26, fig. 10.

Types.-The type locality is Palacio, Chubut. Type material (syntypes) was originally deposited at the Museo Geologico "Giovanni Capellini," Bologna, but is missing in the collections.

Occurrence._- "Banco Nero Inferiore" (Lower Black Layer) of 
the Salamanca Formation (Paleocene) at Palacio, along the coast of Chubut Paleocene (Uliana and Legarreta 1999).

Remarks.-Feruglio (1935, p. 45, pl. 4, fig. 4; 1937, p. 262, pl. 26, fig. 19) described this species as Natica tapiae. However, neither his illustration nor his description suggests that it had even a faint funicle, which is a diagnostic trait for Natica. Therefore, its generic placement lies elsewhere. The shell outline with a fairly well marked shoulder and a rather flat posterior third of the inflated last whorl, straight columellar lip, and strongly impressed suture suggest it may be related to ampullinids possibly close to Tejonia Hanna and Hertlein, 1943. However, of the specimens available to Feruglio, only the figured one seems to have been reasonably complete, albeit the outer lip is missing and only reconstructed in the figure.

\section{TEJONIA ARRoyoensis new species}

Figure 5.1-5.6

1959 Natica sp., Rossi de García, p. 12, pl. 1, fig. 7.

Diagnosis.- Spire short for genus ( $\sim 0.25$ of last whorl height), shoulder narrow, flat, umbilical chink closed, but not covered by callus; very faint cord at base of lip; last whorl tabulate; basal callus thick, growth lines prosocline and slightly sinuous.

Description.- Shell medium-sized ( $38 \mathrm{~mm}$ high, $32 \mathrm{~mm}$ wide); spire with six whorls, 0.25 of last whorl height; last whorl inflated, especially anterior half; suture slightly canaliculated; shoulder narrow, flat; very shallow but conspicuous and wide spiral furrow immediately anterior to shoulder; parietal callus poorly preserved but seemingly narrow and thin; umbilical chink closed, but not covered by callus: basal callus thick and wider than umbilical callus; shell surface smooth, except for prosocline and slightly sinuous growth lines.

Etymology.-From Arroyo Verde (Chubut), type locality of the species.

Types.-MLP-26000 (holotype); CPBA- 20914 (2 paratypes). Occurrence.-Arroyo Verde Formation (Eocene), Arroyo Verde, Chubut, Argentina.

Remarks.-The umbilicus in the North American Tejonia moragai (Stewart, 1927), the type species, is slightly open and the basal cord is more conspicuous. However, the cord in our species is present, although the umbilical chink is hiding most of it. The tabulate last whorl is very similar in the two species. Tejonia arroyoensis n. sp. appears to have a slightly shorter spire.

This species is similar to Tejonia? tapiae (Feruglio, 1935), but the spire is higher and the last whorl is more clearly tabulate in $T$. arroyoensis $\mathrm{n}$. sp. than in the specimen from Palacio (Chubut).

\section{Genus Pseudamaura Fischer, 1885}

Type species.-Natica bulbiformis Sowerby in Sedgwick and Murchison, 1832 (nomen nudum) (=Natica bulbiformis d'Orbigny, 1842 ex Sowerby); by monotypy.

Remarks. - This genus was introduced by Fischer (1885) as a subgenus of Ampullina, and as such was revised by Wolff and Schenk (1972); Cretaceous of Europe.

\section{Pseudamaura dubia (Petersen, 1946)}

Figure 6.1-6.6

1946 Ampullospira dubia Petersen, p. 131, pl. 11, figs. 29, 30.

1994 Pseudamaura? dubia (Petersen, 1946); GRIFFIN AND HünICKEN, p. 264, figs. 4.6, 4.7.

Description.- Shell medium to large (up to $46 \mathrm{~mm}$ high); spire low ( $\sim 0.5$ of last whorl height), with about six whorls; last whorl inflated, especially in lower half; suture slightly canaliculated; shoulder flat on spire whorls, not so clearly defined on last whorl; whorls with shallow concave spiral furrow below shoulder, otherwise evenly convex; parietal callus developed as rather thick and narrow band running between posterior apertural angle and shell base; umbilicus poorly developed as narrow and shallow slit, noticeable only in adults; sheath narrow, bordered by distinct rim; anterior portion of outer lip thickened and partly covering sheath; shell surface with prosocline and slightly sinuous growth lines, spiral ornamentation very faint and restricted to a few indistinct cords on lower half of last whorl.

Types.-Ten syntypes, one of them the specimen illustrated by Petersen; SEGEMAR 9394. Type locality, Piedra Parada, Río Chubut valley, Patagonia, Argentina. Additional material includes four specimens; COR-PZ 2229-2230, COR-PZ 2283.

Occurrence.-The type material comes from the Lefipán Formation (Paleocene) in Chubut, central Patagonia. Additional specimens illustrated in Griffin and Hünicken (1994) (Figs. 4.6, 4.7) and herein comes from the Cerro Dorotea Formation, exposed in the Río Turbio area (southwestern Santa Cruz, Patagonia, Argentina) and the underlying Maastrichtian Cerro Cazador Formation in the same region.

Remarks.-Shell characters such as spire development, the canaliculate suture, the flat shoulder, the inflated last whorl, the very narrow sheath bounded by a rim, and the thick basal lip confirm that this species belongs in Pseudamaura. It was first described as Ampullospira dubia Petersen, 1946. The type material purportedly came from the upper Senonian exposed along the Río Chubut Valley near Piedra Clavada. The source rocks are now included in the Lefipán Formation (Lesta and Ferrello, 1972). This unit, originally believed to be Cretaceous, is now regarded as Paleocene (Medina et al., 1990).

The type species of the genus, i.e., Pseudamaura bulbiformis (Sowerby in Sedgwick and Murchison, 1832), from the Cretaceous of Europe, has a taller shell, the last whorl is more evenly convex, and the sheath is almost completely obliterated (Kase and Ishikawa 2003), in contrast to the South American species, which still retains vestiges of it (see Fig. 6.3).

The type species, Ampullina bulbiformis Sowerby in Sedgwick and Murchison, was also recorded from the Late Cretaceous Arrialoor Group in Southern India (Stoliczcka, 1868, p. 300, pl. 21, figs. 11/15). Some of the specimens (especially Stoliczcka's fig. 14) resemble the material from Patagonia in general shape and spire outline. However, the critical umbilical area is not available for examination. Most specimens from India show a more conspicuous spiral ornamentation that seems to be present over the entire shell surface of some of them.

The North American Ampullina potens Wade in Sohl, 1960 (p. 165, pl. 57, figs. 12, 13) appears to be similar to the Patagonian species. They share the tabulate last whorl, shouldered spire, canaliculate suture and faint spiral cords on the basal half of the last whorl. However, the North American species appears to be smaller, the umbilicus is slightly more open, and the basal lip appears unthickened. In any event, its shell shape, tabulate last whorl, and faint spiral cords it seems to be closer to Pseudamaura than to Ampullina.

Family Naticidae Guilding, 1834 Subfamily Naticinae Guilding, 1834

Remarks.-In this subfamily we include species previously grouped in Poliniceinae Finlay and Marwick, 1937. According to the arrangement by Bouchet and Rocroi (2005), Polinicinae Gray, 1847 , is a junior synonym of Naticinae Guilding, 1834. We follow this taxonomic arrangement as fossil species generally do not show enough of the characters necessary for further discrimination (i.e., opercula, radulae). None of the Cenozoic species from Patagonia recognized by us show any hint of characters (i.e., shell shape, ornamentation) that may allow placement in any of the other two subfamilies of Naticidae, i.e., Sininae Woodring, 1928, and Globisininae Powell, 1933. 


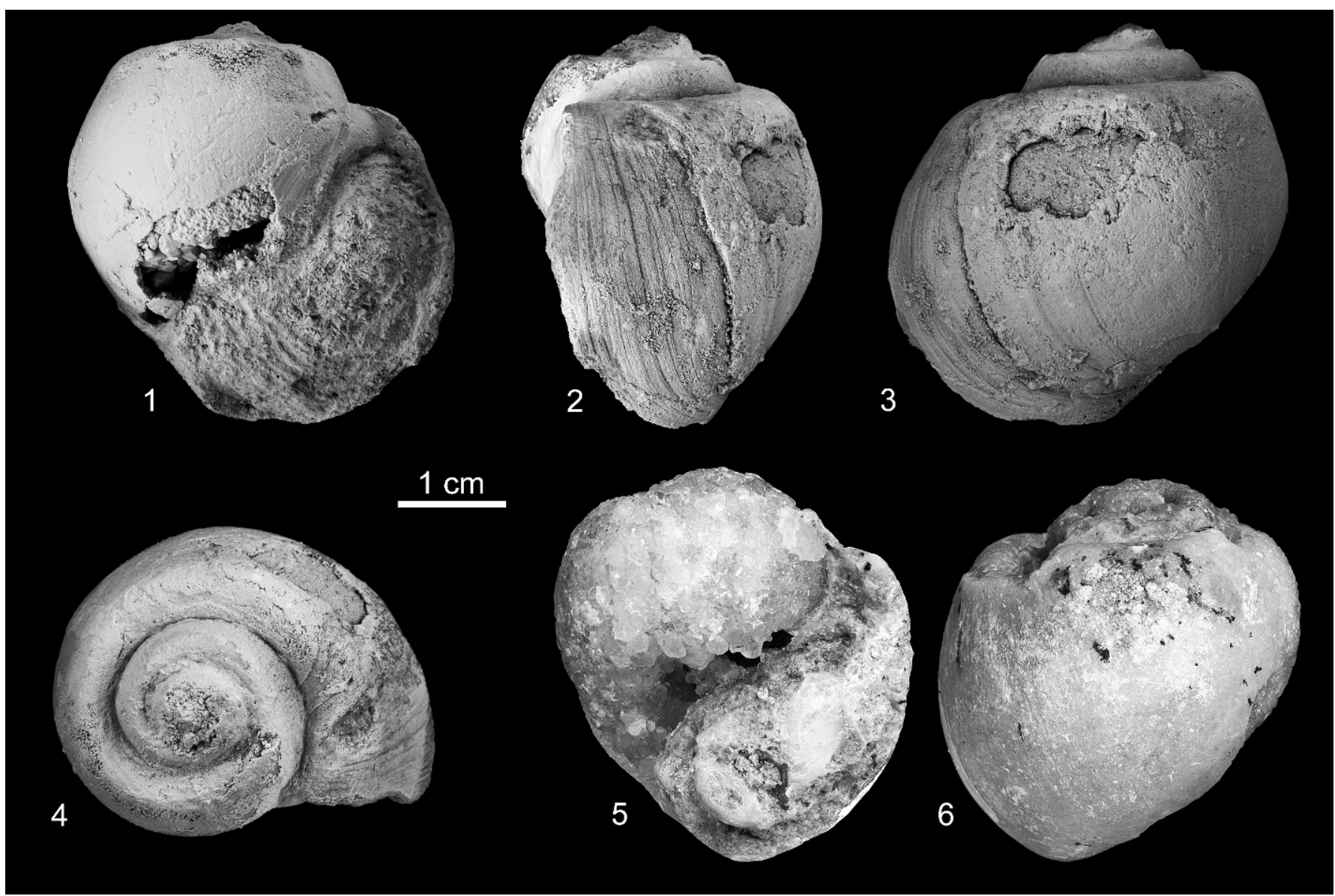

FigurE 5-Tejonia arroyoensis n. sp. 1-4, holotype MLP-26000; 5, 6, paratype, CPBA-20914.

Genus Natica Scopoli, 1777

Type species.-Nerita vitellus Linnaeus, 1758; subsequent designation by Anton, 1839; Recent of the Indo-Pacific.

Remarks.-This genus, characterized by a well-developed funicle in the umbilicus, is widespread in Cenozoic outcrops of the Northern Hemisphere. Many of the South American species of Naticidae were initially placed in this genus, but most of them have proved to belong elsewhere. The material described below is too poorly preserved to allow a definite taxonomic placement, and therefore the original generic placement is retained.

\section{"NATICA" ENTRERIana Borchert, 1901}

1901 Natica entreriana sp. n., BORCHERT, p. 57, pl. 5, fig. 19.

1998 Euspira consimilis (Ihering, 1897); MARTÍNEZ CHIAPPARA, DEl Río AND Reichler p. 34, pl. 15, fig. 22 only (original figure of Borchert, 1901).

Types.-Holotype not found in the MACN-PI- collection. Type locality, Paraná, Entre Ríos.

Occurrence.-Paraná Formation (late Miocene).

Remarks.-The figure is rather poor, but it shows an open umbilicus and a funicle, features also mentioned by Borchert in his description (1901, p. 57, pl. 5, fig. 19). The generic placement of this species must remain uncertain until further specimens are collected in which generic characters are properly preserved. However, it certainly does not belong in Natica, judging from the umbilical characters. Brunet (1997) and Martínez Chiappara et al. (1998) stated that this species was a synonym of Lunatia consimilis (Ihering), but the two species can be readily separated, as L. consimilis lacks a funicle and clearly belongs in Euspira.
Therefore, the status of this species in the northern Patagonian fauna remains doubtful.

Genus Euspira Agassiz in J. Sowerby, 1837

Type species.-Natica glaucinoides Sowerby, 1812 (non Deshayes, 1832) $(?=$ Natica labellata Lamarck, 1804); subsequent designation by Bucquoy et al. 1883; Eocene of Europe.

Remarks.-This genus of globose to globose-elongate shells, with an open umbilicus and a slender to indistinct umbilical callus, includes several species living off the Patagonian coast (Pastorino, 2005). It is easily recognizable in Miocene material from Patagonia originally described as Natica or Polinices.

Euspira PATAgOnica (Philippi, 1845)

Figure 7.1-7.3

1845a Natica patagonica Ph., PHILIPPI, p. 65.

1845b Natica patagonica Ph., PhilipPI, p. 41, pl. 2, fig. 2.

1897 Natica consimilis sp. n., IHERING, p. 283, fig. 12.

1899 Natica famula Ph., IHERING, p. 28.

1907 Polynices magellanica consimilis Ih., IHERING, p. 156 (part).

1914 Polynices magellanica consimilis Ih., IHERING, p. 85 (part).

1996 Lunatia magellanica Hombron and Jacquinot, 1834 (in error pro 1854); PARODIZ, p. 214 (part).

2005 Euspira patagonica (Philippi, 1845); PAStorino, p. 242, figs. $84-101$

Description.-Shell small- to medium-sized (up to $\sim 30 \mathrm{~mm}$ high), globose, thin ( $\sim 0.5 \mathrm{~mm}$ thick at outer lip); spire medium, 


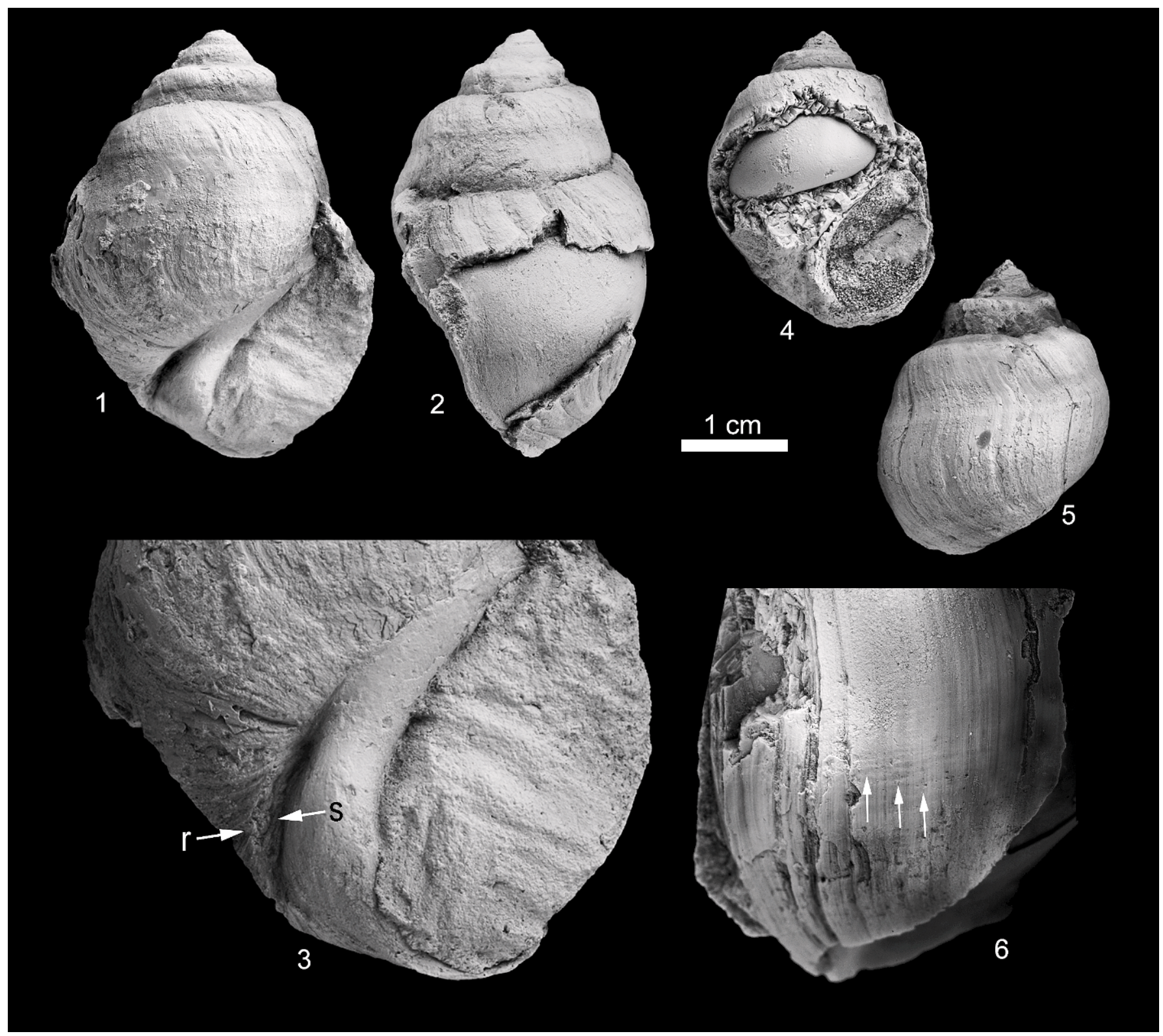

Figure 6-Pseudamaura dubia (Petersen, 1946), lot COR-PZ-229 (two specimens). 1, apertural view; 2, lateral view; 3, detail of umbilical area; 4, apertural view; 5, abapertural view; 6 , detail of lateral view, arrows showing weak spiral ornamentation. Abbreviations: $\mathrm{r}=$ rim; $\mathrm{s}=$ sheath.

$\sim 0.33$ of total height; five convex whorls, last whorl covering less than half of previous whorl; suture clearly impressed; shell surface smooth, except for faint growth lines; parietal callus thin, poorly developed, subrectangular; virtually no umbilical callus; columellar lip straight, slightly thickened, but not forming a true callus; basal lip slightly thickened at angle with columellar lip, then rapidly thinning towards outer lip; basal lip weakly reflected; umbilicus open, narrow, smooth inside.

Types.-The type material of Euspira patagonica was discussed by Pastorino (2005) and is housed in the Museo Nacional in Santiago (Chile). Type locality, La Cueva, Santa Cruz.

In his original description of Natica consimilis, Ihering (1897, p. 283) described his species based on only one specimen, and there is no indication that he had any other material at that time, despite the fact that Ihering himself (Ihering, 1914, p. 85) labeled the two specimens from La Cueva numbered MACN-PI-672 as
"Typus." One can not assume from the original description that he actually did have the two specimens available at that time. In any event, his lectotype designation (Ihering, 1914) does not meet the requirements of Article 74.6 of the ICZN (1999). Thus, the specimen he described and figured, of which the measurements he provided in his original description agree completely, is deemed to be the holotype and is illustrated herein in Figures 7.1-7.3.

Additional material includes, MACN-PI-673, ten specimens from Santa Cruz, all decorticated to some degree; MACN-PI-674, one specimen, from Golfo San Jorge; whether this specimen belongs in E. patagonica (as Natica consimilis) needs confirmation. Its very different preservation elicits doubts as to its exact provenance and it appears that there may have been some misplacement of the material.

Occurrence.-Monte León Formation (early Miocene).

Remarks.-This is a relatively uncommon species in the Monte León Formation, possibly because of —as in Bulbus subtenuis- 


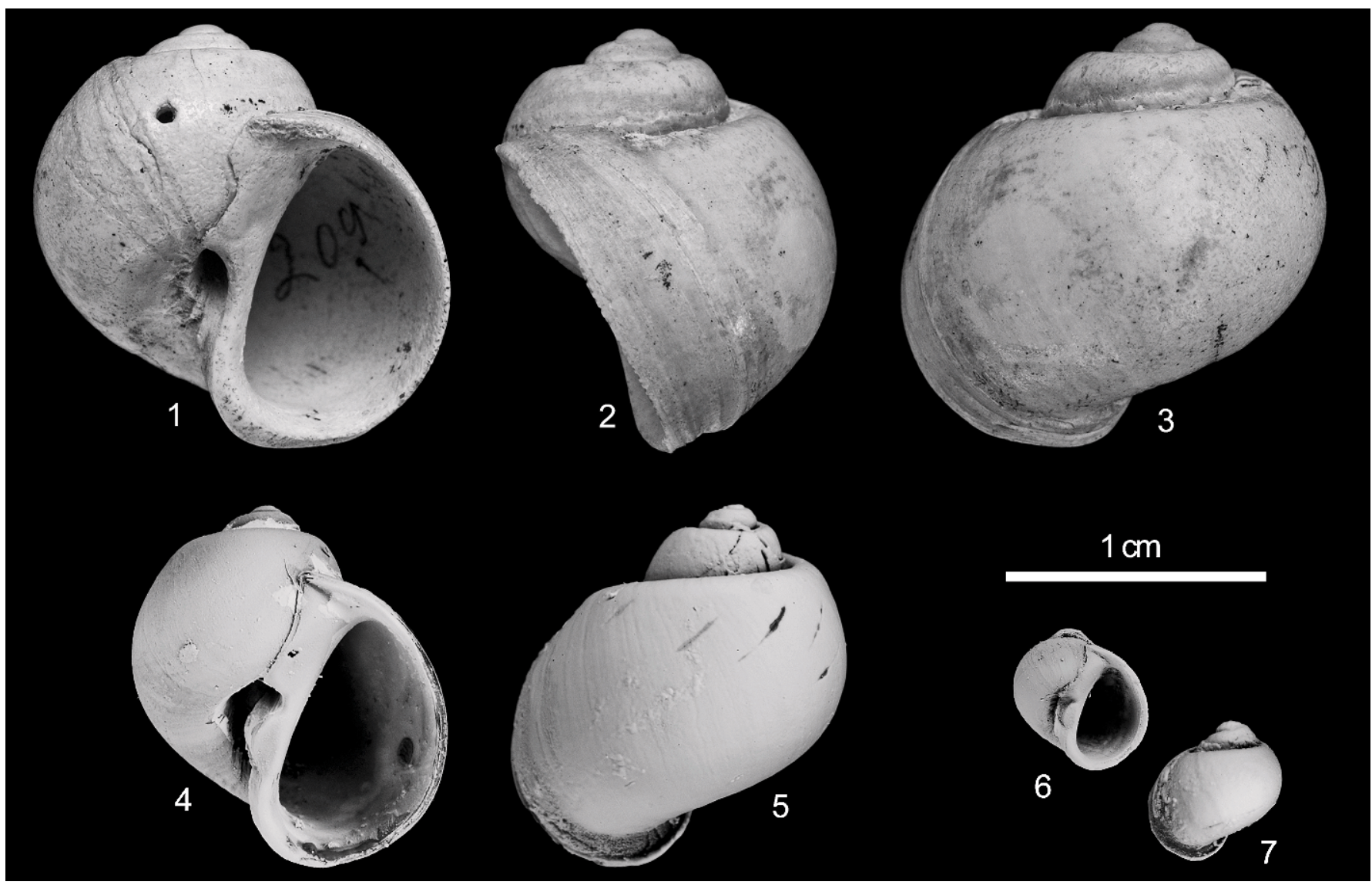

FIguRE 7-1-3, Euspira patagonica (Philippi, 1845), holotype of Natica consimilis Ihering, 1897, MACN-PI-672; 4-7, Notocochlis borreloi (Brunet, 1995): 4, 5, holotype, MPEB-PI-145; 6, 7, holotype of Natica pastorei Brunet, 1995, MPEB-PI-127.

its rather thin shell. The shells are quite distinct from all other naticids recorded from Neogene rocks in Patagonia and can be readily separated from them because of their open smooth umbilicus, impressed suture and globose shape. The complete lack of a columellar callus and the slightly reflected basal lip are enough to separate it from the superficially similar Bulbus subtenuis. Euspira patagonica (Philippi, 1845) inhabits the shelf along the coast of Patagonia, the Straits of Magellan, Staten Island, and South Georgia and Falkland (Malvinas) Islands (Pastorino, 2005).

A specimen in the Ihering Collection (MACN-PI-675) was identified by Ihering himself as Polynices magallanica consimilis. It comes from the "Araucano" in Puerto Deseado (i.e., Pliocene?). The specimen is very decorticated and broken, but the thick shell, apparently devoid of umbilicus, indicates that it cannot be identified with the material from Santa Cruz.

\section{Genus Notocochlis Powell, 1933}

Type species.CCochlis migratoria Powell, 1927; (=Natica gualteriana Récluz, 1844); original designation; Recent, New Zealand.

Remarks.-Natica Scopoli, 1777, has been used for a number of Natica-like species now placed in other genera such as Notocochlis Powell, 1933, Tanea Marwick, 1931, Naticarius Duméril, 1806 and Tectonatica Sacco, 1890. It is very difficult to differentiate these genera based on shell characters alone, especially in fossil species in which the shells are not perfectly preserved. Kilburn (1976) separated Natica, Tanea, Naticarius and Tectonatica on the basis of opercular or radular differences. At the same time, he doubted the validity of Notocochlis. According to Kabat (2000), this is a valid pan-tropical genus, sometimes confused with Natica, although they are phylogenetically distinct. Majima (1989) separated it from Naticarius Duméril, 1806 (type species, Nerita canrena Linnaeus, 1758), because of the more closed umbilicus and less tabulate whorls, in addition to opercular features. These shell characters appear to be present in the Patagonian material described below - and in the extant Patagonian Notocochlis isabelleana (d' Orbigny, 1840), according to Pastorino (2005) — allowing it to be placed in Notocochlis.

Notocochlis BorRelloi (Brunet, 1995)

Figure 7.4-7.7

1995 Natica (Natica) borelloi, n. sp., BRUnet, p. 41, pl. 4, fig. 5.

1995 Natica (Natica) pastorei, n. sp., BRUnET, p. 40, pl. 4, fig. 4.

1998 Euspira consimilis (Ihering, 1897); MARTínez CHIAPPARA, DEl Río AND Reichler, p. 34, pl. 2, figs. 9-12; pl. 23 , fig. 3 only.

Types.-MPEF-PI-145 (holotype); MPEF-PI-127, one specimen from Puerto Pirámide, Chubut (holotype of Natica pastorei); Puerto Madryn Formation. Type locality, Puerto Pirámide, Chubut. Additional material, FCDP 2361, one specimen from San Juan, Uruguay (pl. 23, fig 3 only of Martínez Chiappara et al., 1998); Camacho Formation.

Occurrence.-Puerto Madryn Formation (late Miocene).

Remarks.-This is one of the two species of Natica described from the Puerto Madryn Formation by Brunet (1995). The two species he described, however, are synonyms, because Natica pastorei is only a decorticated specimen of $N$. borrelloi, and 
cannot be differentiated by any other character beside the lack of funicle, a structure clearly missing because the shell is decorticated.

Brunet compared Natica borrelloi with Natica marochiensis (Gmelin), a species which Borchert had previously compared with his Natica entreriana from Paraná. Although Ihering (1907) placed Natica entreriana in Polinices, such a placement seems to be erroneous. Borchert's illustrated specimen appears to be closer to Natica than to Polinices, as suggested by the presence of a conspicuous funicle. Natica borrelloi and Natica entreriana are very similar, but the species from Patagonia has a better developed parietal callus and a slightly thicker shell. Further investigations may prove that the specimen from Entre Ríos is a juvenile of this species. Unfortunately, at present there are no specimens available of Borchert's species so its status must remain uncertain.

Martínez Chiappara et al. (1998) included Natica pastorei, together with Natica entreriana, in Euspira consimilis (Ihering). As pointed out above, the species from Entre Ríos and Chubut seem to belong in different groups. Beyond the fact that there are no specimens of Natica entreriana for comparison, the specimen from Chubut clearly belongs in $N$. borrelloi. The holotypes of the two species come from the same locality.

\section{Genus Bulbus Brown in Smith, 1839}

Type species.-Bulbus smithi Brown in Smith, 1839; monotypy; (=Natica fragilis Leach, 1819); Recent in the North Atlantic.

Remarks.-This cool-water genus is characterized by it thin shell and sigmoidally curved inner margin of the aperture that sometimes covers the slightly open umbilicus. The earliest record of this genus is from early Miocene deposits in Fukushima, Japan. The species described herein from the Monte León Formation (also early Miocene) is the earliest one known from the Southern Hemisphere. The paleobiogeographic history of the genus remains poorly understood, as most other species are known from the Arctic, North Atlantic, and North Pacific regions. However, it has also been reported living off the coast of Patagonia (Bulbus carcellesi Dell, 1990) and Antarctica (Bulbus scotianus Dell, 1990, and Bulbus benthicolus Dell, 1990). The new Zealand genus Globisinum Marwick, 1924 (type species, Sigaretus drewi Murdoch, 1899, from Kai Iwi, New Zealand, middle Pleistocene and Recent) resembles Bulbus in shell shape and thickness and in radular characters, but they are obviously different as all species of Globisinum carry evident spiral cords and the living ones lack an operculum, a feature present in living species of Bulbus. While phylogenetic affinities remain uncertain, it could be possible that the two genera shared a Cretaceous ancestor before the arrival of Globisinum in New Zealand.

\section{Bulbus subTenuis (Ihering, 1897)}

Figure 8.1-8.6

1897 Natica subtenuis sp. n., IHERING, p. 284, fig. 13.

Description.-Medium-sized (up to $33 \mathrm{~mm}$ high), globose and thin-shelled, with at least five whorls in adult stages; spire very short-less than one-fifth of aperture height; suture gently impressed; last whorl evenly inflated throughout; last whorl covering almost three-fourth of previous whorl at aperture angle; sculpture of closely packed incremental growth lines; growth lines more noticeable on base of last whorl; shell thin, not over 1 $\mathrm{mm}$ thick in last whorl; aperture almost perfectly semi-circular, inclined $\sim 15^{\circ}$ from coiling axis; parietal callus very thin and poorly developed, not spreading beyond imaginary line joining umbilicus and aperture angle; umbilical and columellar lip very slightly thickened; umbilical chink narrow, but distinct; anterior lip slightly thickened.
Types.-MACN-PI-692 (holotype; monotypy). Type locality, Yegua Quemada, Santa Cruz. Additional material, MLP-26002; MLP-26017, eight specimens from Estancia San Julio, Tierra del Fuego; Carmen Silva Formation; GHUNLPam-20000, two specimens from Cuevas de Monte León; Monte León Formation.

Occurrence.-Monte León (early Miocene).

Remarks.-This species is placed in Bulbus because of its thin, smooth and globose shell, with a slit-like umbilicus, and lack of a conspicuous callus. Species of Bulbus have minute spirals, which are not visible on the holotype because they are worn off.

The type species of this genus is Bulbus smithi Brown in Smith, 1839 (p. 104, pl. 1, fig. 18), from off the coast of Scotland. According to Marincovich (1977, p. 335) and Majima (1989, p. 32 ) it is a junior synonym of Natica fragilis Leach, 1819 (Appendix 2, p. 62), from the western North Atlantic. Dell (1990, p. 153) and Kabat (1991, p. 427) also endorse this synonymyalbeit not explicitly. On the other hand Abbott (1974, p. 156) and Rosenberg (2009) listed the two species as separate entities. Regardless of the taxonomic status of the type species - a matter beyond the scope of this paper — we believe that Bulbus subtenuis shows similarities to the specimens described and illustrated by Marincovich (1977) as Bulbus fragilis (Marincovich, p. 335, pl. 31, fig. 5), a Holocene specimen from St. Peter's Bank, North Atlantic. The two taxa share the same inflated and low-spired thin shell, with a semicircular aperture and a straight columellar lip. The northern specimen, however, seems to be slightly shouldered, the umbilical chink is almost absent, and the spire appears to be somewhat higher than in the species from Tierra del Fuego.

Another extant species that shows similarities with Bulbus subtenuis is Bulbus carcellesi Dell, 1990 (p. 155, fig. 259; Pastorino 2005, p. 236, figs. 56-59) from the mid- to outer shelf and upper slope along the coast of Argentina and the Falkland (Malvinas) Islands. The living species has a slightly taller spire and also the shell surface is very gently concave beneath the suture and appears to be ornamented with faint spiral threads, features not found in the fossil species.

The Patagonian species shows remarkable similarities in shell shape and thickness to species of the New Zealand genus Globisinum Marwick, 1924 (type species Sigaretus drewi Murdoch, 1899; original designation). The type species of Globisinum was based on a specimen from the Castlecliffian from Kai Iwi, near Wanganui, New Zealand. The holotype, illustrated by Marwick (1924, p. 576, pl. 60, fig. 11, 15) is very similar in all respects to the specimens from Patagonia. The similarity between Bulbus and Globisinum was already noticed by Dell (1990, p. 155). He pointed out, however, that they could be separated by the presence of an operculum in Bulbus, an anatomical feature missing in Globisinum. Obviously, the operculum is hardly ever preserved in the fossil record. Therefore, its presence or absence in fossil species can not be confirmed. In such cases, placement of fossil species in genera of which a diagnostic feature is the presence of an operculum can only be tentative, as it is based necessarily on other shell characters. However, all species of Globisinum show weak but nevertheless conspicuous spiral cords. The shell of Bulbus subtenuis resembles that of Globisinum drewi (=Globisinum venustum [Suter, 1907]; see Marwick, 1924, p. 576, pl. 60, fig. 10) very closely in all features, except for the spiral ornamentation, which is absent in the Patagonian species (at least as far as can be seen in the available material). All other naticids from the Monte León and Carmen Silva formations belong in entirely different genera and can be easily separated from this species.

Stilwell and Zinsmeister (1992, p. 110, pl. 14, figs. n, o) illustrated material from the Eocene La Meseta Formation in Seymour Island (Antarctica) which they believed were 


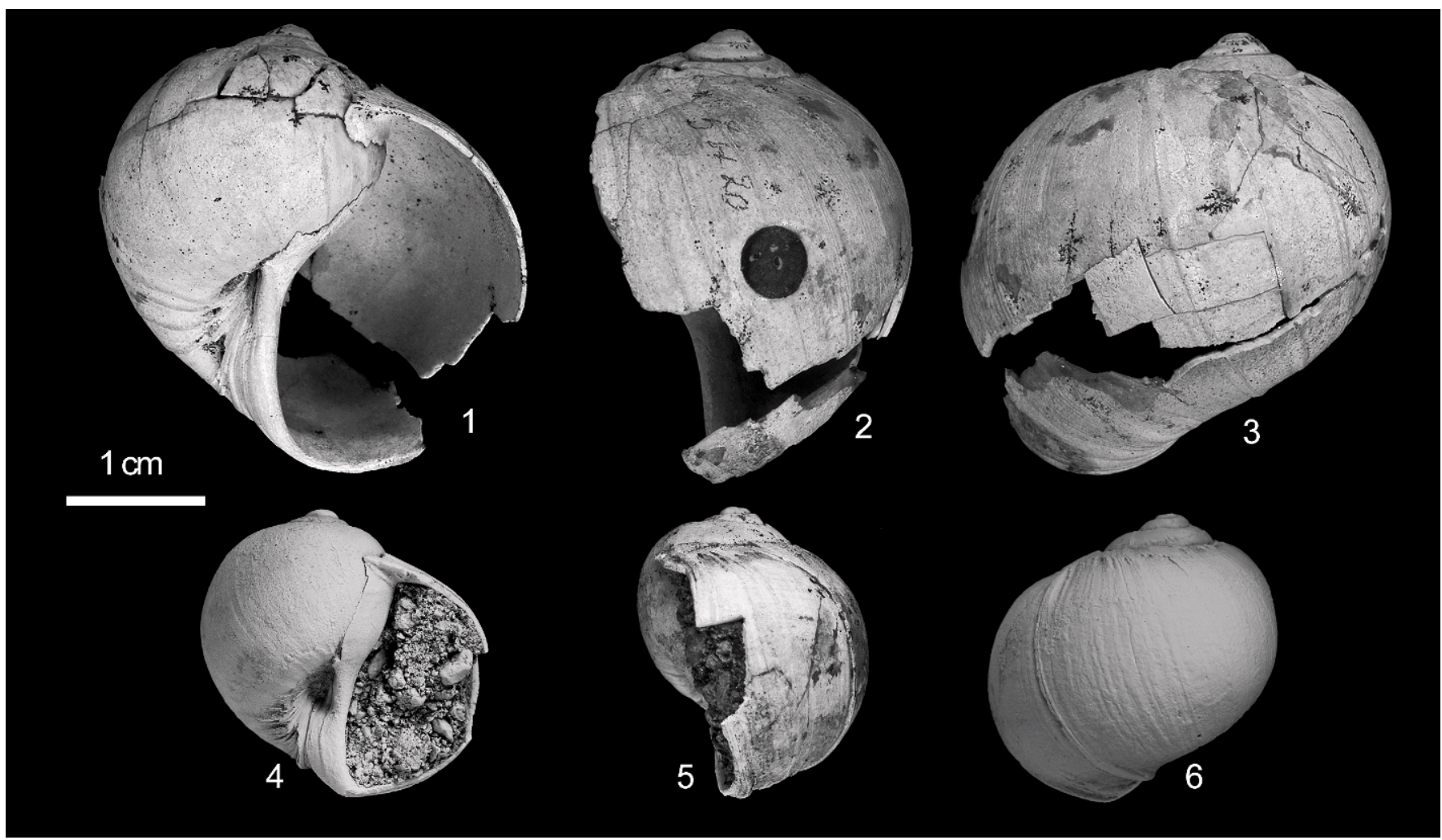

FIgURE 8-Bulbus subtenuis (Ihering, 1897). 1-3, holotype, MACN-PI-692; 4-6, MLP-26002.

comparable to Polinices subtenuis (Ihering, 1897). However, their specimens are clearly different from Ihering's holotype and also from our specimens from Tierra del Fuego. The Antarctic material includes thick-shelled naticids with a typical Polinices callus; they are probably adult specimens of Polinices marambioensis Stilwell and Zinsmeister, 1992 (p. 111, pl. 14, figs. p-r), also from the same unit (see further comments under Polinices puntarenasensis below).

Beu (2009, p. 216) stated that Polinices subtenuis Ihering belonged in Glossaulax Pilsbry, 1929. However, none of the specimens from Antarctica show the characteristic groove across the umbilical callus. Thus, they cannot be referred to Glossaulax, and their correct generic placement remains uncertain.

Genus Polinices Montfort, 1810

Type species.-Polinices albus Montfort, 1810; original designation; Recent in the Indo-Pacific.

Remarks.-Many species of Polinices have been described from Cenozoic rocks in New Zealand (Beu and Maxwell, 1990), Japan (Majima, 1989) and other parts of the world (Marincovich, 1977), but the relationships within this genus remain as yet obscure, due to the lack of sufficient shell characters. In this paper we agree with Majima (1989) in considering the following combinations of character states as distinctive for this genus: smooth shell, umbilicus open, with a well developed umbilical callus, umbilical wall grooved anteriorly, and a very shallow but distinct groove at intersection of parietal and columellar calluses. As Majima (1989) pointed out, a number of "informal groups" may be recognized within the Japanese representatives of this genus. This may also hold true for South American species. However, proper delimitation of such groups must necessarily wait until a full character analysis of the genus is carried out, which is beyond the scope of this work.
Polinices SANTACRUZENSIS Ihering, 1907

Figure 9.1-9.7

1846 Natica solida, Sowerby, p. 612, pl. 3, fig. 40 (non Blainville, 1825 p. 251) (part).

1897 Natica solida Sowerby; IHERING, p. 280.

1907 Polynices santacruzensis, sp. n., IHERING, p. 152, pl. 4, fig. 15.

1996 Polynices santacruzensis, PARodiz, p. 266.

Description.-Medium sized inflated shell, with approximately five to six whorls in adult stages, spire short, less than one-third of aperture height; suture adpressed; last whorl greatly inflated, rounded basally, but with a very indistinctly concave shoulder along suture line; last whorl covering more than two-thirds of previous whorl at apertural angle; sculpture of closely packed incremental growth lines; growth lines more noticeable on base of last whorl than elsewhere; shell moderately thick, to $\sim 1.5-2 \mathrm{~mm}$ thick in last whorl; aperture semi-lunar, inclined $\sim 25^{\circ}$ from coiling axis; parietal callus thick, especially at apertural angle, with a very shallow transverse groove at its base; umbilical callus narrower, except at middle, where it is considerably thicker because of the presence of an umbilical ridge; umbilicus open, relatively wide, rounded; umbilical ridge rounded, but well marked and running up the umbilicus bounded by two shallow grooves, the abapical one weaker than the adapical; larger specimens with umbilical callus weakly constricted basally, with constriction separating it from greatly thickened anterior inner lip.

Types.-Syntypes, MACN-PI-680, seven specimens; Cañada de los Artilleros; base of the Santa Cruz Formation. MACN-PI681, five specimens; Yegua Quemada; Monte León Formation. MACN-PI-682, twelve specimens; La Cueva; Monte León Formation. The syntypes come from Cañada de los Artilleros, Santa Cruz (MACN-PI-680), Yegua Quemada (MACN-PI-681), and La Cueva (MACN-PI-682); Santa Cruz Province. 


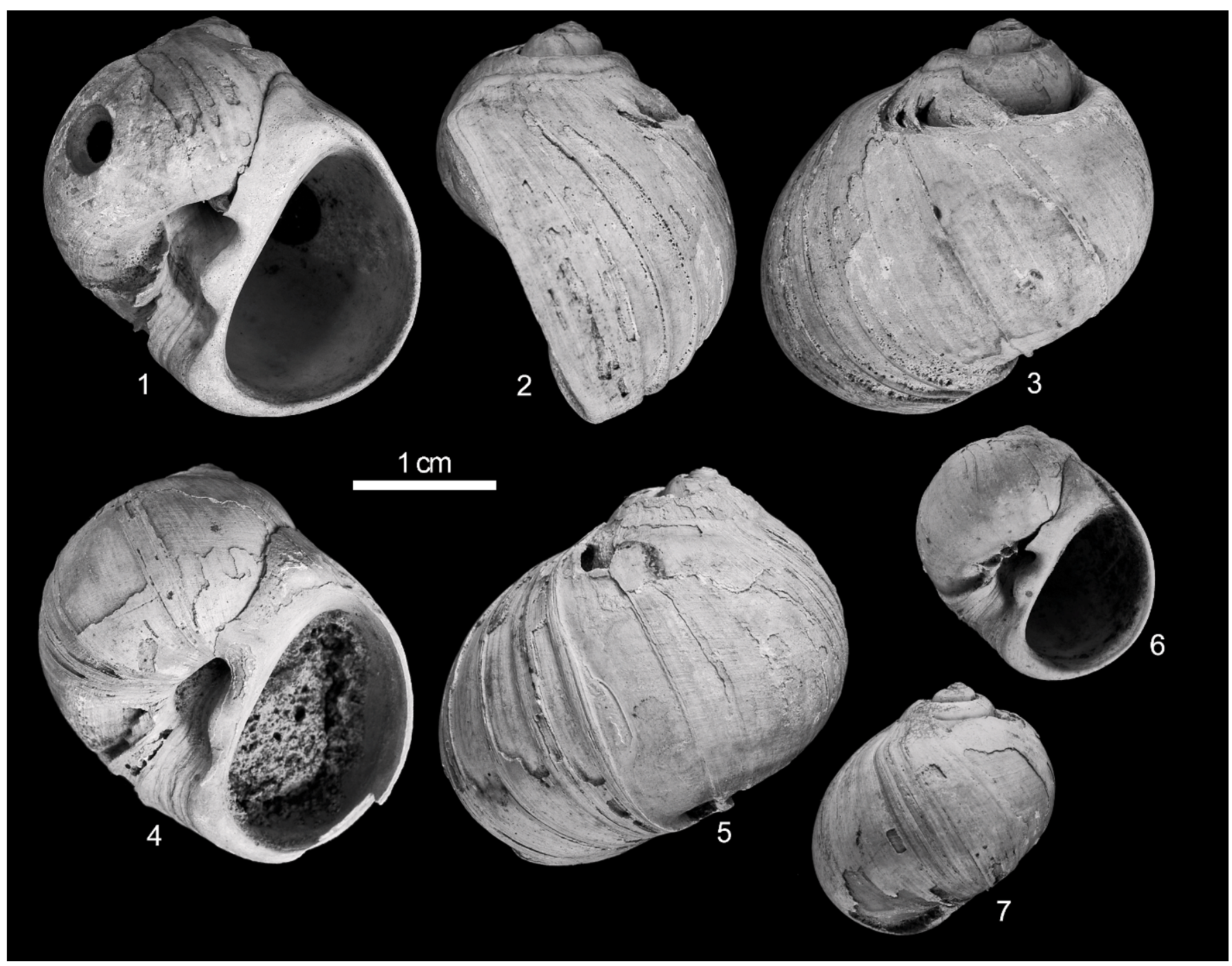

Figure 9-Polinices santacruzensis Ihering, 1907, syntypes. 1-3, MACN-PI-680; 4, 5, MACN-PI-681; 6, 7, MACN-PI-682.

Additional material, CPBA-6616, three specimens from Las Cuevas; Monte León Formation. CPBA-8790a, one specimen from Mount Entrance, Santa Cruz; Monte León Formation. CPBA-9381a, four specimens from Las Cuevas; Monte León Formation. CPBA-13005, one specimen from Playa La Mina; San Julián Formation. CPBA-16033, one specimen from Puerto Santa Cruz; Monte León Formation. CPBA-20917, one specimen from Cañadón de los Misioneros; Monte León Formation. MZSP52468, one specimen from Cañada de los Artilleros; base of the Santa Cruz Formation. MZSP-52474, one specimen from Cañada de los Artilleros; base of the Santa Cruz Formation. MLP-26018, three specimens from Cabeza de León; Monte León Formation. GHUNLPam-20001, eleven specimens from Cabeza de León; Monte León Formation, Muestra 8. GHUNLPam-20002, three specimens from Cuevas de Monte León; Monte León Formation, Muestra 6.

Occurrence.-Base of Santa Cruz Formation and Monte León Formation (early Miocene).

Remarks. - Sowerby (1846) described Natica solida based on material from Navidad, Chile, and he illustrated a specimen from Santa Cruz which he included doubtfully in this species, as he was not convinced that the material from the two localities was conspecific. Sowerby's (1846) figure 40 is of a specimen from Santa Cruz and figure 41 from Navidad. As they seem to be two different taxa, and he himself included the material from Santa Cruz in his new species with a query, the specimens from Santa Cruz do not have any type status. D'Orbigny (1852, p. 39) realized that the name was preoccupied and introduced the name Natica subsolida for all the material described by Sowerby. Unaware of this, Hutton (1886, p. 214), who also realized that the name was preoccupied, used the replacement name Natica darwini for Sowerby's material plus additional new specimens he had from South Canterbury, New Zealand. Ihering used the name Natica solida for several specimens he had from Yegua Quemada and La Cueva, in Santa Cruz (Ihering 1897, p. 280; 1899, p. 29). In 1902, Ortmann (p. 198, pl. 33, fig. 4) used Natica darwini for a suite of specimens from Santa Cruz and Upper Río Chalia, also in Santa Cruz. The figured specimen was referred correctly to Glossaulax secunda by Ihering (1907, p. 155). The status of the other specimens remains uncertain. At the same time, Ihering realized that the material from Santa Cruz and from Navidad were different from each other and from the material from New Zealand referred also to Natica darwini by Hutton. He restricted the use of Natica darwini for the specimens from Chile, while he proposed $P$. huttoni n.n. for the New Zealand specimens and Polynices santacruzensis Ihering, 1907 (p. 152, pl. 4, fig. 15) for the specimens from Santa Cruz. Sowerby's specimens have no type status, and Ihering did not designate a type in his original publication. Griffin and Nielsen (2008, p. 305, pl. 23, figs. 12, 13) 
commented on the status of $N$. solida, stating that specimen NHMUK 26342 should be regarded as Sowerby's illustrated holotype. This specimen, labeled "Santa Cruz" in the Darwin collection, is quite different from the other two specimens also labeled Santa Cruz. In view of the close resemblance of that specimen undoubtedly coming from Navidad in Chile to the species commonly occurring there and assigned to Magnaticaand no Magnatica had been previously reported from Santa Cruz - the type status of the specimen appears to be reasonable (Griffin and Nielsen, 2008).

This species from Santa Cruz is quite similar to the Pliocene species Polinices waipipiensis (Marwick, 1924) (p. 564, pl. 59, fig. 11). This species was further discussed by Beu and Maxwell (1990, p. 295, pl. 37f), who included in it three species also described by Marwick, i.e., Uber pateaensis Marwick, 1924 (p. 564, pl. 59, fig. 10); Uber ovuloides Marwick, 1924 (p. 565, pl. 59, fig. 7); and Polinices stanleyi Marwick, 1948 (p. 30). According to them, $P$. waipipiensis and $P$. pateaensis are deeply and shallowly umbilicate variants of one species, and Polinices stanleyi a more heavily callused form. As to Polinices ovuloides, it could be either a narrower distinct species or else represent males of Polinices waipipiensis. In any event, the type specimens of Polinices pateaensis and Polinices ovuloides show a groove (deeper and more conspicuous in Polinices pateaensis) crossing the umbilical callus as observed in Glossaulax. On the other hand, the holotype of $P$. waipipiensis is very similar to $P$. santacruzensis in shell shape, in the callus with a slight constriction between the umbilical callus and the thickened basal lip, in the angle between the aperture plane and the coiling axis, and in the concave sutural ramp.

\section{PoliniCES PUNTARENASENSIS Ihering, 1907}

Figures 10.1-10.14, 11, 12.3-12.5

1899 Natica chiloënsis Philippi; Ortmann, p. 431.

1900 Natica ovoidea Philippi; Ortmann, p. 380.

1902 Natica chiloënsis Philippi; Ortmann, p. 186, pl. 33, fig. $1 \mathrm{a}, 1 \mathrm{~b}$.

1902 Natica ovoidea Philippi; Ortmann, p. 187, pl. 33, fig. 2. 1905 Natica chiloensis Philippi; WILCKENS, p. 165.

1907 Polynices puntarenasensis, n.n., IHERING, p. 341

1907 Polynices jorgensis, sp. n., IHERING, p. 158, pl. 5, fig. 19.

1907 Polynices famula Philippi; Ihering, p. 158, pl. 5, fig. 20 (non Philipi, 1887, pl. 10, fig. 13a) (part).

2010 Magnatica hansi sp. nov; ReICHLER, p. 205, pl. 4, figs. 5-7.

Description.-Medium- to large-sized inflated shell (up to 56 $\mathrm{mm}$ high in the largest specimen), with approximately five whorls in adult stages; protoconch smooth, of about three whorls; spire short, about one-fifth of aperture height; suture adpressed; last whorl greatly inflated, rounded basally, but with a very indistinctly concave shoulder along suture line; last whorl covering more than two-thirds of previous whorl at aperture angle; sculpture of closely packed incremental growth lines; shell thick, reaching over $2 \mathrm{~mm}$ thick in last whorl; aperture semilunar, inclined $\sim 30^{\circ}$ from coiling axis; parietal callus thick, especially at aperture angle, with a shallow but conspicuous transverse groove at its base; groove much fainter in juvenile specimens than in adults; umbilical callus narrower, tapering anteriorly; large specimens with constriction separating umbilical callus from thickened basal inner lip; juveniles with inner and outer margins of parietal callus sub-parallel, rendering callus roughly rectangular in shape; basal lip callus solid and wide; umbilicus open, in part covered by expansion of umbilical callus, which in some cases leaves only an umbilical chink, sometimes completely closed; umbilical ridge faint, running up the umbilicus bounded by a shallow indistinct anterior spiral groove; sculpture of weak growth lines only, but decorticated specimens exhibiting very faintly marked spiral lines; apparent color pattern preserved on some specimens, i.e., those tightly imbedded in the bearing rock.

Types.-Most syntypes of Polinices puntarenasensis are in the Hatcher collection, formerly at the Department of Earth and Atmospheric sciences, Purdue University, IN, U.S.A., now in the Paleontological Research Institute, Ithaca, NY, U.S.A. MACNPI-678, three syntypes (sent by Ortmann to Ihering) from the Lower Magellanian Beds, Punta Arenas, Chile. MACN-PI-671, one specimen from Golfo San Jorge, Cabo Tres Puntas (holotype of $P$. jorgensis Ihering, 1907, illustrated in fig. 12C-E); Chenque Formation. Type locality is Punta Arenas, Chile.

Additional material, MLP-26003-26007, eighty-nine specimens from Estancia San Julio, Tierra del Fuego (Coll. Griffin and Pastorino); Carmen Silva Formation. CPBA-20913, sixteen specimens from Tierra del Fuego; Carmen Silva Formation. CPBA-20915, three specimens from Tierra del Fuego; "Magallaniano." CPBA-6540, three specimens from Castillo, Tierra del Fuego; Carmen Silva Formation. MACN-PI-669, two specimens from Yegua Quemada; Monte León Formation. MACN-PI-670, five specimens from Cañada de los Artilleros, one of them illustrated (Ihering, 1907, pl. 5, fig. 20); base of the Santa Cruz Formation. MLP-26001, 26008-26010, forty-nine specimens from San Sebastián, Tierra del Fuego; Carmen Silva Formation. MLP-26011, nine specimens from Puesto El Cachimbo, Estancia Sara, Tierra del Fuego; Carmen Silva Formation. MACN-Pi 4812 (holotype of Magnatica hansi Reichler, 2010), MACN-Pi 4813 (paratype of Magnatica hansi Reichler, 2010).

Occurrence.-Possibly Miocene. The exact age of the Magellanian Beds has not been accurately established yet, but the specimens come from horizons II and III of Hatcher (1897). These are the upper horizons of the "Magellanian." and possibly equivalent to the Carmen Silva Formation in northern Tierra del Fuego. Saladar Member (lower and middle sections), Gran Bajo del Gualicho Formation.

Remarks.-The first reference to material belonging in this species was by Ortmann (1899), who referred it to Natica chiloensis Philippi, (1887, p. 84, pl. 10, fig. 12). He did not illustrate his material at this time, but later published a further description and figures of two specimens he collected near Punta Arenas (Chile). It is obvious from his figures (Ortmann, 1902, pl. 33, fig. 1a-b) that these specimens do not belong in Natica chiloensis, a fact already noticed by Ihering (1907). Natica chiloensis comes from Neogene rocks exposed along the western coast of Chiloe and shows clear differences from the specimens illustrated by Ortmann. Specimens of Natica chiloensis illustrated by Philippi show a wider last whorl, an open umbilicus, a narrower parietal callus and a small umbilical callus that appears to reflect the presence of a narrow and weak spiral rib within the umbilicus, albeit not clearly depicted in his illustration. Ihering (1907, p. 341) was aware of these differences and hence proposed the new specific name Polinices puntarenasensis, which we use here. Ihering was also right in assuming that Wilckens' reference to Natica chiloensis from Carmen Silva was in fact $P$. puntarenasensis, as there are no shells that can be even remotely assigned to Natica chiloensis in any of the localities where the Carmen Silva Formation is exposed in Tierra del Fuego, and Polinices puntarenasensis is one of the commonest shells in this unit.

Polinices jorgensis Ihering, 1907 (p. 158, pl. 5, fig. 19) comes from further north, along the coast of the San Jorge Gulf, in beds referable to the Chenque Formation (Bellosi, 1995). The holotype is a poorly preserved specimen. The outer shell layer is here preserved, although as a calcite replacement, and thus the true nature of the sutural area is revealed, showing that it is not impressed or canaliculate as could be supposed based on Ihering's or Ortmann's specimens, but instead is adpressed. The syntypes 


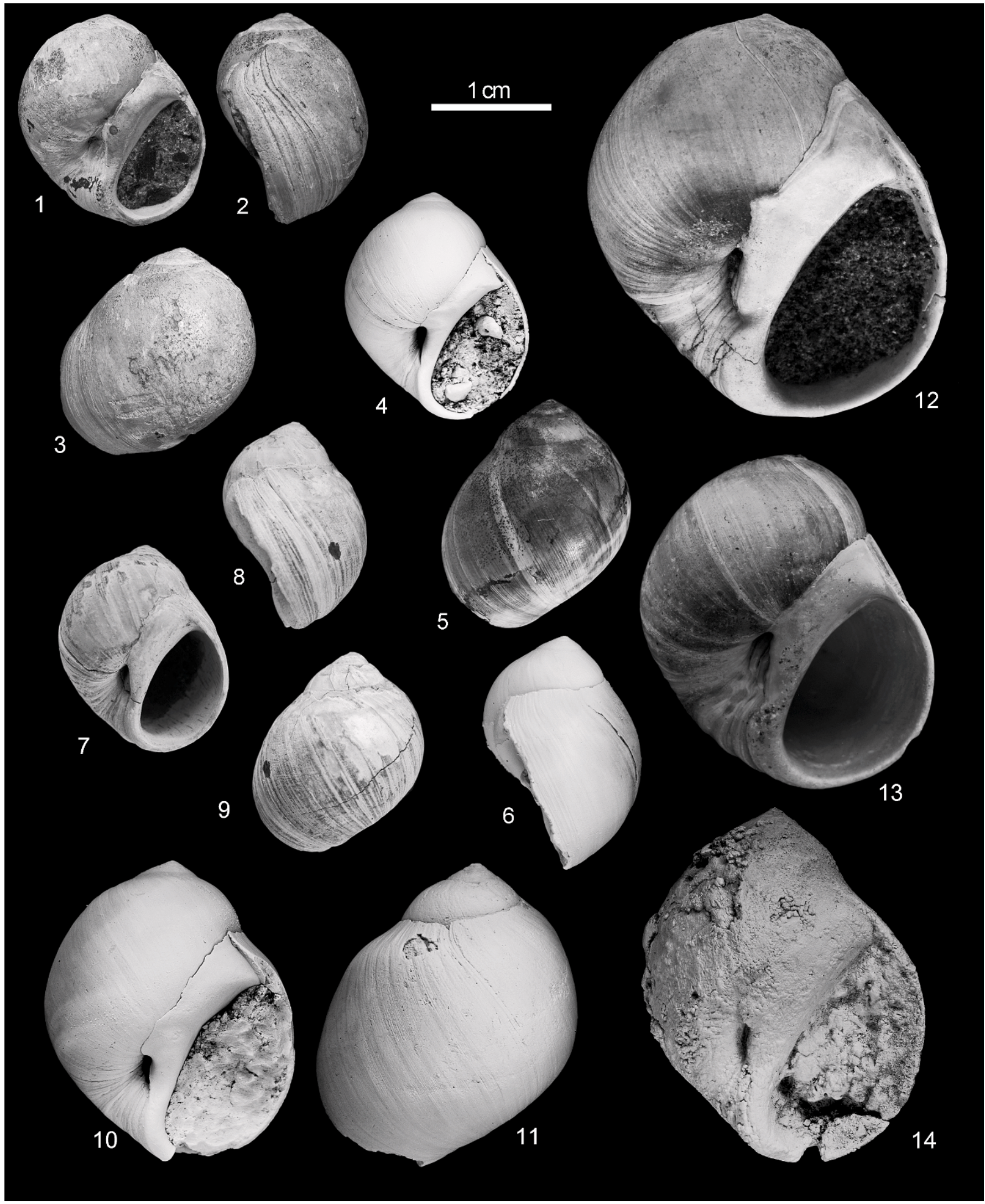

FIGURE 10 - Polinices puntarenasensis Ihering, 1907. 1-3, MACN-PI-678, syntypes; 4-6, MLP-26008, 4 and 6 coated with magnesium; 7-9, CPBA-20913; 10, 11, MLP-26003, coated with magnesium; 12, MLP-26004; 13, MLP-26009; 14, MACN-PI-4812, holotype of Magnatica hansi Reichler, 2010, coated with Magnesium. 


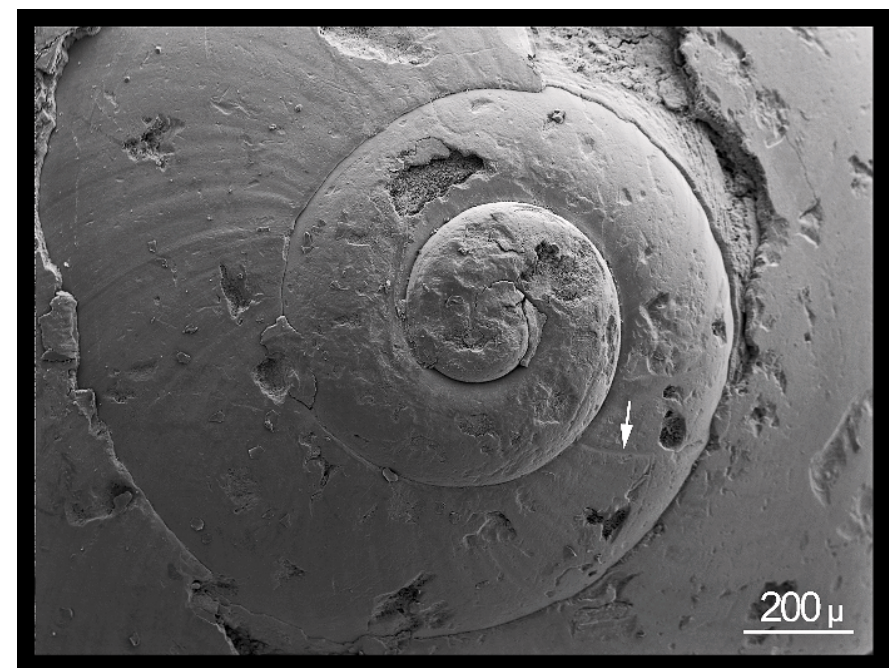

FIGURE 11-Polinices puntarenasensis Ihering, 1907, MLP-26001, SEM of protoconch (coated), arrow pointing transition to teleoconch.

are missing the outer layer, and thus the spire shows a more "scalariform" appearance.

Polinices puntarenasensis is very common in the Carmen Silva Formation of Tierra del Fuego and is quite similar to Polinices santacruzensis Ihering, 1907. Yet, it can be separated from the Patagonian species because of its taller spire, its more oblong shape and its much narrower or even closed umbilicus, which never has the spiral rib so conspicuous as in the species from Santa Cruz; this absence or extreme reduction of the umbilical ridge is a consequence of the straight and narrow columellar lip.

A specimen referable to Polinices puntarenasensis was illustrated by Malumián et al. (1979, pl. 2, fig. 4). This specimen was collected at a quarry in Estancia la Federica, in Tierra del Fuego. Unfortunately, further stratigraphic and locality data are unavailable.

The size, shell outline and umbilical and callus characters of Magnatica hansi Reichler 2010 (p. 205, pl. 4, figs. 5-7) are entirely similar to those of the type material of $P$. puntarenasensis. Particularly, the thick anteriorly tapering umbilical callus, the narrowly open umbilicus partly covered by the expanded umbilical callus, and the slight constriction seperating the umbilical callus from the thickened basal lip indicate that the species from Gran Bajo del Gualicho is a junior synonym of the southern Patagonian species.

Polinices (Polinices) cf. P. (P.) subtenuis (Ihering, 1897) sensu Stilwell and Zinsmeister (1992, p. 110, pl. 14, figs. $n-0)$ from the Eocene La Meseta Formation in Seymour Island (Antarctica) has the same shell outline but the umbilical features are quite different. The umbilicus is never open in the Antarctic species and the parietal and umbilical calluses are wider. The latter shows a deeper constriction bounding the anterior portion of the callus, a feature missing in the specimens from Tierra del Fuego. The shells are also thicker in the Eocene species. "Polinices" (Polinices) marambioensis Stilwell and Zinsmeister, 1992 (p. 111 , pl. 14, figs. p-r) is a juvenile of $P$. ( $P$.) subtenuis sensu Stilwell and Zinsmeister, and very different from the juvenile specimens of Polinices puntarenasensis we have examined. The identity of the two Antarctic taxa could be confirmed after examining a large suite of specimens from different growth stages housed in the collection at the Universidad Nacional de La Pampa. The generic status of this Antarctic species is, however, doubtful, and its inclusion in Polinices seems to be unwarranted because of the absolute lack of the shallow groove, even if sometimes very slightly marked, separating the parietal from the umbilical callus. According to Beu $(2009$, p. 210, 212, 216) the species from Antarctica should be referred to Falsilunatia Powell, 1951 (type species, Natica soluta Gould, 1847). The status of the type species and the distinction of this genus from Euspira were discussed by Pastorino (2005). We conclude that it cannot be referred to Falsilunatia, a genus based on radular morphology; the shell of the type specimen (from where the radula was taken) is clearly different from the Antarctic shells in many features, but mainly by the presence of a constriction at the base of the parietal callus, a feature missing in all specimens from Antarctica.

\section{"Polinices" oRTMANNI Ihering 1907 nomen dubium} Figure $12.1,12.2$

1907 Polynices Ortmanni, n. n., Ihering, p. 157, pl. 5, fig. 18.

Material.-MACN-PI-677, one specimen from Santa Cruz, illustrated in Ihering, 1907, pl. 5, fig. 18.

Remarks.-Ihering introduced Polinices ortmanni as a new name for Natica ovoidea Philippi sensu Ortmann (1900; see also Ortmann, 1902, p. 187, pl. 33, fig. 2). Ihering also mentioned two specimens in his own collection. The specimen illustrated by Ihering (1907, pl. 5, fig.18) came from Santa Cruz, as did also the one figured by Ortmann (1902, pl. 33, fig. 2). The second specimen from Santa Cruz in Ihering's collection is missing. The third syntype in Ihering's collection (MACN-PI-676) comes from Yegua Quemada. However, this is possibly a misplaced specimen, as it does not agree in morphology, size, or other visible characters, with the description provided by Ihering. Furthermore, the peculiar preservation of his specimen is unknown in any other mollusc from Yegua Quemada.

The differences that Ihering claimed to recognize between his Polinices ortmanni and his Polinices puntarenasensis cannot be assessed because the former was based on specimens showing a high degree of decortication and in which the features of the inner lip and umbilical area are missing. The apparently channeled suture, which is similar to that of Friginatica Hedley, 1916, is nothing but an artifact of decortications. Therefore, the status of $P$. ortmanni must necessarily remain doubtful, as it is impossible to refer Ihering's type material to any of the other naticid taxa present in the Monte León Formation or other units of similar age.

\section{Polinices mina new species}

Figure 13.1-13.9

Diagnosis.-Polinices with medium-size shell (up to $45 \mathrm{~mm}$ high), spire over one-third of aperture height; callus thick, posterior groove shallow but distinct; umbilical callus tapering into basal lip; base of parietal callus with shallow and narrow groove.

Description.-Medium sized inflated shell (up to $45 \mathrm{~mm}$ high in the largest specimen); spire with approximately five whorls in adult stages, over one-third of aperture height; suture adpressed; last whorl greatly inflated, rounded basally, but with a distinctly concave shoulder along suture line; last whorl covering just over one-half of previous whorl at aperture angle; sculpture of closely packed incremental growth lines; shell moderately thick, reaching $\sim 1.4-1.8 \mathrm{~mm}$ thick in last whorl; aperture semi-lunar, inclined $\sim 40^{\circ}$ from coiling axis; parietal callus thick, especially at aperture angle, with a shallow but distinct transverse groove at its base; non-grooved umbilical callus generally tapering uniformly into thickened basal lip, but in some specimens separated from it by a weak constriction; umbilicus open, narrow; shallow and narrow umbilical furrow running up within umbilicus.

Etymology.-From Playa La Mina, near San Julián, province of Santa Cruz, the type locality of this species. 


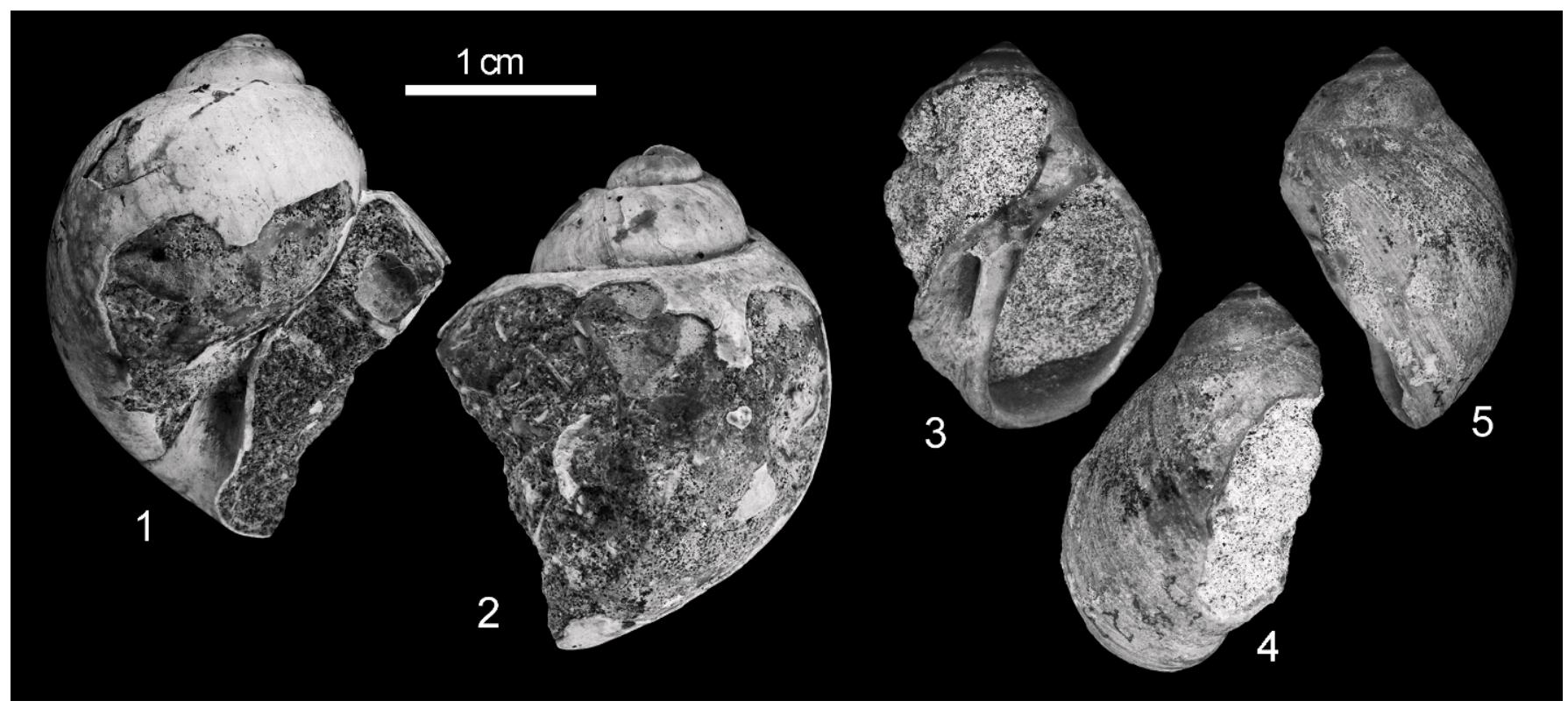

Figure 12-1, 2, "Polinices" ortmanni Ihering, 1907, holotype, MACN-PI-677; 3-5, Polinices puntarenasensis Iherring, 1907, MACN-PI-671, holotype of "Polinices" jorgensis Ihering, 1907.

Types.-MLP-26012, holotype; MLP-26013-26014, paratypes. Type locality, Playa La Mina, San Julián, Province of Santa Cruz. Additional material, MLP-26015, seventeen broken, worn and slightly deformed specimens, all from Playa La Mina, Santa Cruz; San Julián Formation.

Occurrence.-San Julián Formation (latest Oligocene-early Miocene).

Remarks.-This new species can be separated from Polinices santacruzensis Ihering (1907, p. 152, pl. 4, fig. 15) by its higher spire, by the narrower umbilicus devoid of the strong umbilical callus found in $P$. santacruzensis, by the umbilical wall with a shallow and narrow groove, and by the greater angle between the aperture plane and the coiling axis.

This new species can be differentiated from adult specimens of Polinices puntarenasensis Ihering (1907, p. 41) by its narrower umbilicus and its well defined concave subsutural shoulder, in addition to the much more pronounced angle between the aperture plane and coiling axis.

\section{Genus Glossaulax Pilsbry, 1929}

Type species.-Natica reclusiana Deshayes, 1839; original designation; Recent in the eastern Pacific.

Remarks.-The transverse groove incising the umbilical callus is a characteristic shared by all species of this genus, setting it apart from similar taxa such as Neverita Risso and Polinices Montfort. Fossil species of Glossaulax are common in Cenozoic rocks worldwide (although not in Australia or New Zealand) (Marincovich 1977; Majima 1989). Material described by earlier authors from Patagonia referred to other naticid genera may be easily placed in Glossaulax when specimens with complete umbilical calluses are available.

Glossaulax Secundum (Rochebrune and Mabille, 1885) Figures 14.1-14.8, 15.1-15.14

1885 Natica secunda, Rochebrune And Mabille, p. 103.

1885 Natica omoia, Rochebrune and Mabille, p. 103.

1887 Natica Vidali Philippi; PhilıPPI, p. 85, pl. 10, fig. 17.

1887 Natica obtecta Philippi; PhILIPPI, p. 82, pl. 10, fig. $2 \mathrm{~b}$ only (not fig 2a) (part).

1897 Natica solida Sowerby; IHering, p. 280.
1897 Natica obtecta Philippi; IHERING, p. 282.

1899 Natica obtecta Philippi; Ihering, p. 27.

1907 Polynices pyrotheriana, sp. n., IHERING, p. 154, pl. 5, fig. 17.

1902 Natica secunda Rochebrune and Mabille; Ortmann, p. 188, pl. 33, fig. 3a, 3b.

1902 Natica darwini Hutton; Ortmann, p. 189, pl. 33, fig. 4.

1995 Neverita (Glossaulax) groeberi, n. sp., BRUNET, p. 39, pl. 4 , fig. 2.

1995 Neverita (Glossaulax) keideli, n. sp., BRUnEt, p. 40, pl. 4, fig. 3.

1996 Lunatia pyrotheriana (Ihering); PArodiz, p. 259.

1998 "Glossaulax" groeberi Brunet; Martínez ChIAPPARA, del Río and Reichler, p. 35, pl. 2, fig. 15, 16.

Description.-Shell medium-sized (up to $\sim 55 \mathrm{~mm}$ high), globose in form; spire very low, not surpassing one-fifth of total height; shell moderately thickened; sutures adpressed; last whorl greatly inflated, rounded basally, evenly convex throughout; last whorl covering more than three quarters of previous whorl; shell smooth, with very subtly marked incremental growth lines; shell thin, less than $1.8 \mathrm{~mm}$ thick in last whorl; of largest specimen; aperture subovate, elongated, inclined $\sim 25^{\circ}$ to coiling axis; parietal callus thick, especially at apertural angle; umbilical callus wide; transverse callus groove shallow but distinct; umbilicus slightly open in some specimens, completely covered by callus in others; no funicle present; anterior lip not thickened.

Types.-The holotypes of Natica secunda and Natica omoia are housed in the Malacology Collection of the Museum national d'Histoire naturelle, Paris (unnumbered). The syntypes of Natica obtecta Philippi are housed in the Museo Nacional de Historia Natural, in Santiago (Chile). The syntypes of Polynices pyrotheriana Ihering are housed in the Ihering collection, MACN-PI-679 (Buenos Aires). The holotype of "Glossaulax" groeberi Brunet is housed in the Museo Paleontológico Egidio Feruglio, MPEF-PI-143 (Trelew) together with the holotype of Neverita (Glossaulax) keideli Brunet, MPEF-PI-144. Type locality, Santa Cruz.

Additional material, MACN-PI-4768, one specimen from Cañadón de los Misioneros; Monte León Formation. MACN-PI- 


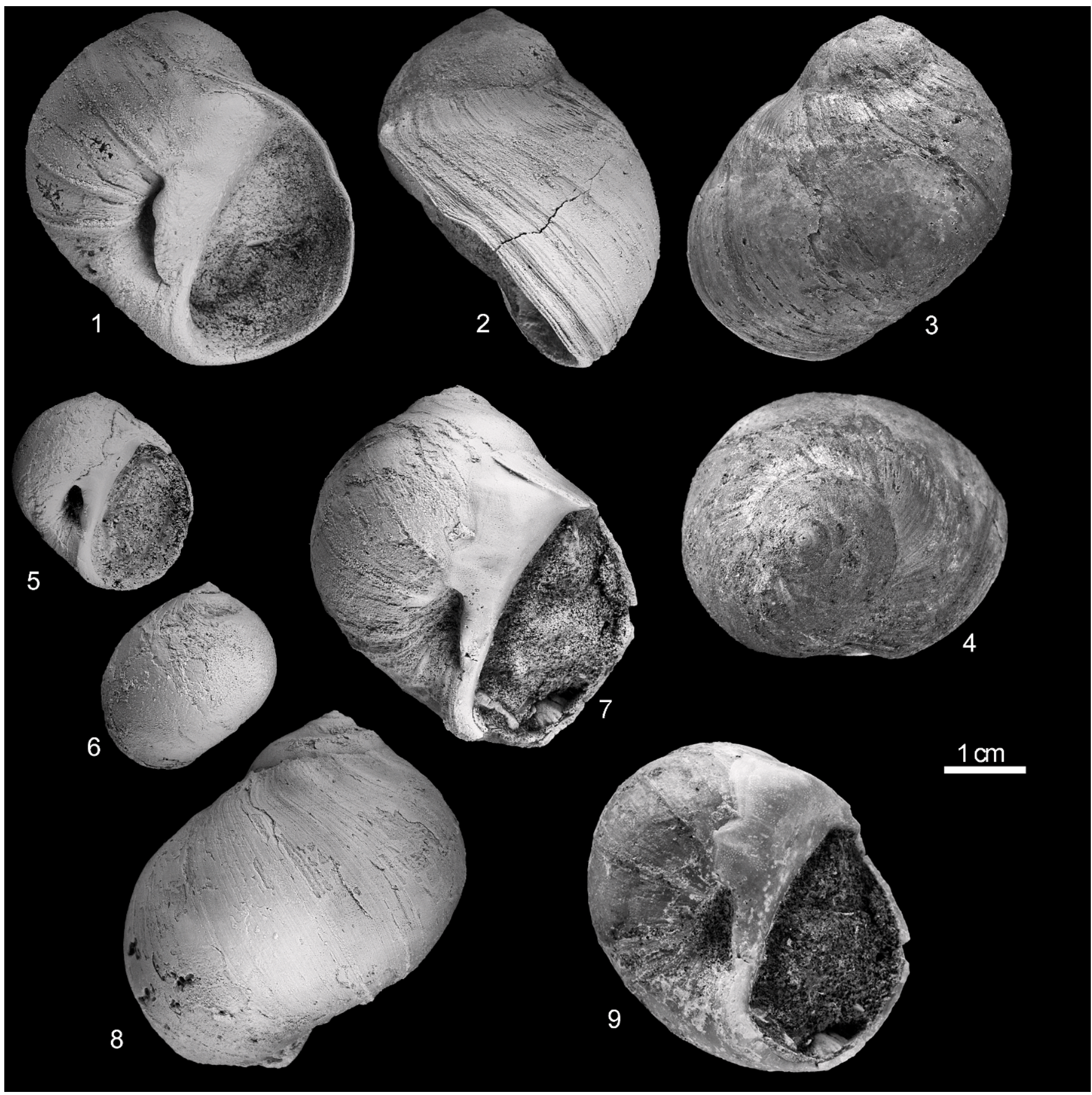

Figure 13-Polinices mina n. sp. 1-4, holotype, MLP-26012; 5, 6, paratype, MLP-26014; 7-9, paratype, MLP-26013.

6622, two specimens from Cañada de los Artilleros; base of the Santa Cruz Formation. MACN-PI-4154, six specimens from Río del Carbón (=Arroyo de la Mina), Epuyén, province of Chubut; "Patagoniano." CPBA-8744, seven specimens numbered and nine unnumbered (B1-B9) from Monte León; Monte León Formation. CPBA-8752, one specimen from Cañada de los Artilleros; base of the Santa Cruz Formation. CPBA-8778, 16024-16030, seven specimens from Cañadón de los Misioneros; Monte León Formation. MLP-26016, seven specimens from Mount Entrance, Santa Cruz; Monte León Formation. CPBA-20916, five specimens from Cañadón de los Misioneros; Monte León Formation. CPBA-20911, nine specimens from Las Cuevas; Monte León Formation. CPBA-20912, one specimen from Cañadón de los
Misioneros, Santa Cruz; Monte León Formation. MZUSP52467, six specimens from the base of the section at Cañada de los Artilleros; base of the Santa Cruz Formation. MACN-PI-679, five specimens (all syntypes-one of them illustrated-of Polynices pyrotheriana Ihering) from Camarones, Chubut; "Estratos con Monophoraster y Venericor." MACN-PI-683, seven specimens from Santa Cruz; Monte León Formation. MACN-PI-684, twelve specimens from Cañada de los Artilleros; base of the Santa Cruz Formation. MACN-PI-685, one specimen from Manantial Salado, San Julián; San Julián Formation. MACN-PI-686, three specimens from Golfo San Jorge, Cabo Tres Puntas; Chenque Formation. MACN-PI-688, four moulds from Santa Cruz; Monte León Formation. MACN-PI-689, one specimen from Yegua 


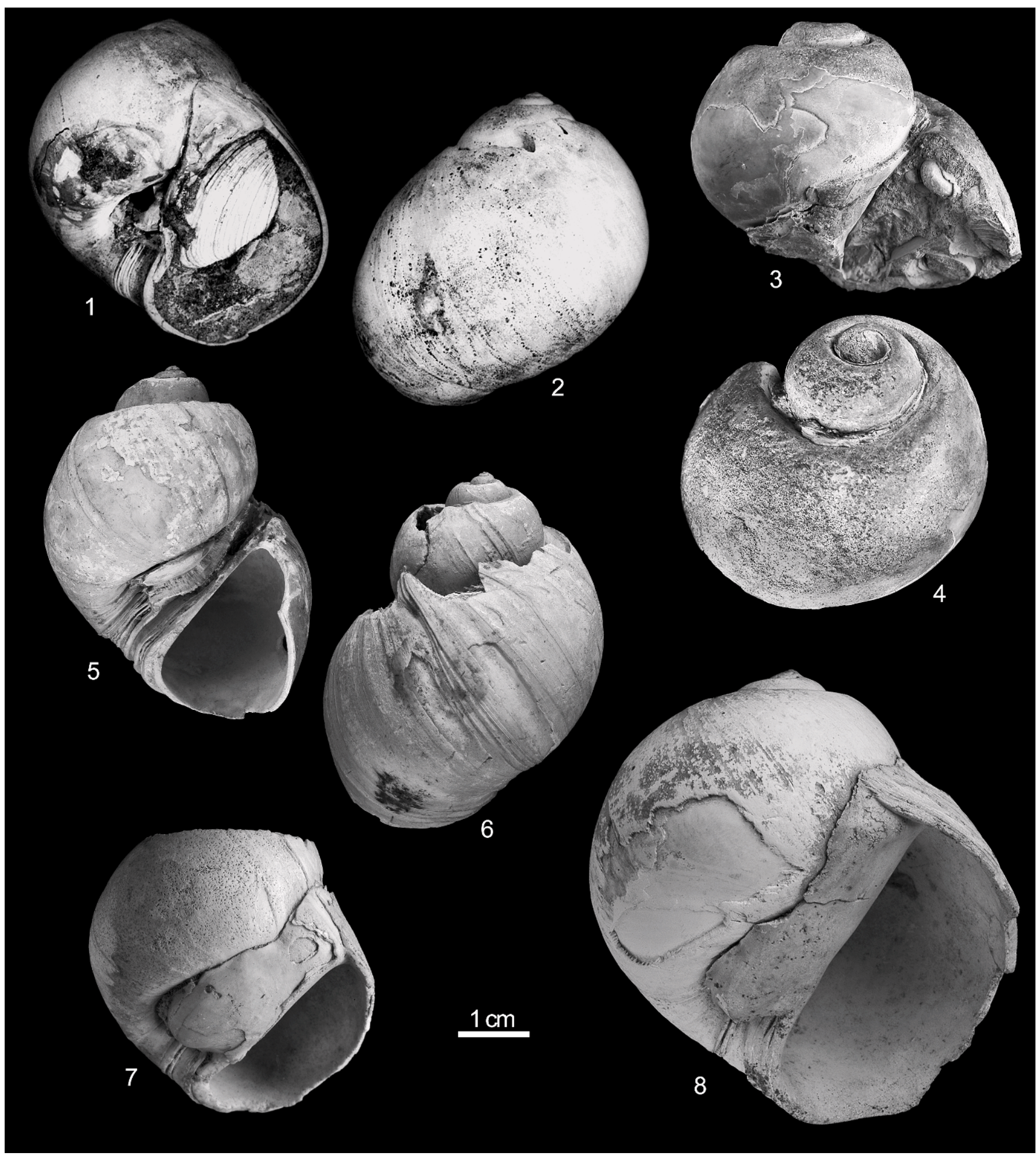

FiguRE 14 - Glossaulax secundum (Rochebrune and Mabille, 1885). 1, 2, syntype of Natica omoia Rochebrune and Mabille, MHNP unnumbered; 3, 4, syntype of Natica secunda Rochebrune and Mabille, MHNP unnumbered; 5, 6, syntype of Polynices pyrotheriana Ihering, 1907, MACN-PI-679; 7, another syntype of Polynices pyrotheriana Ihering, 1907, MACN-PI-679; 8, MACN-PI-689.

Quemada; Monte León Formation. MACN-PI-690, four specimens from La Cueva; Monte León Formation. MLP-7328, one specimen from "Chubut"; "Patagoniano"(?). MLP-1422, two specimens from Bahía Sanguinetti, Santa Cruz Province, Chenque Formation; MLP-9781, four specimens from Subida de Montenegro, near Comodoro Rivadavia, Chubut; Chenque Formation.
Occurrence.-San Julián Formation, Monte León Formation, Base of Santa Cruz Formation, Chenque Formation, unnamed Formation in North East Chubut (early Miocene).

Remarks.-Natica secunda Rochebrune and Mabille (1885, p. $103 ; 1889$, H.30), is based on a single imperfectly preserved specimen from Santa Cruz. As pointed out by Ihering, Natica 


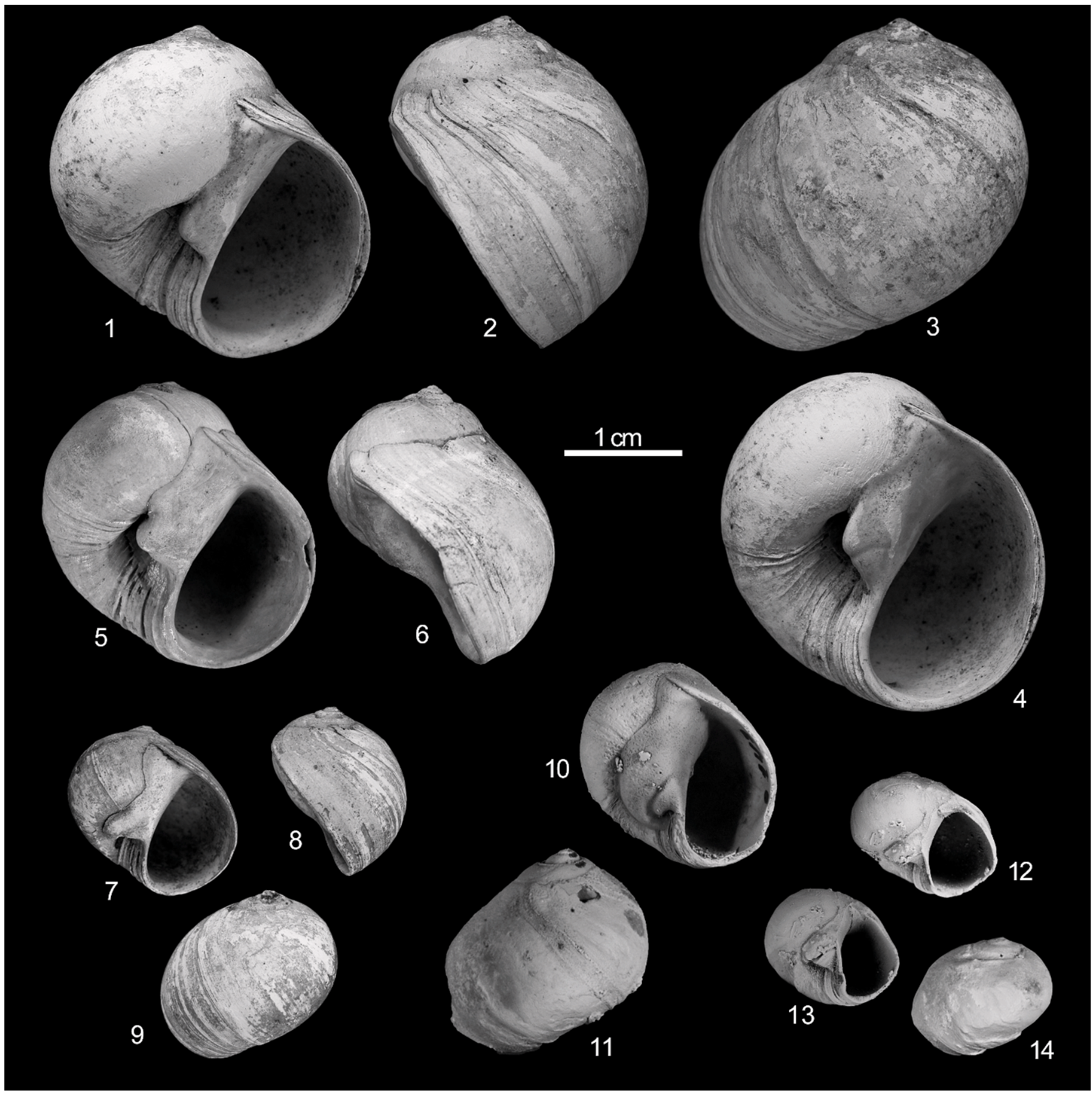

FiguRE 15-Glossaulax secundum (Rochebune and Mabille, 1885). 1-4, MZUSP-52467; 5, 6, MACN-PI-684; 7-9, MACN-PI-684; 10, 11, holotype of Neverita (Glossaulax) groeberi Brunet, 1995, MPEF-PI-143; 12-14, holotype of Neverita (Glossaulax) keideli Brunet, 1995, MPEF-PI-144.

secunda is just a badly preserved specimen of Natica omoia Rochebrune and Mabille (1885, p. 103; 1889, H. 31). The specific name secunda has been previously used in the literature and therefore, as first revisers we choose this name instead of omoia, despite the better preservation of the type material of the latter.

Figure $2 \mathrm{~b}$ of Natica obtecta Philippi $(1887$, p. 82 , pl. 10, fig. $2 b$ ) is of a specimen from Santa Cruz that also belongs in this species, as noted previously by Ihering (1907, p. 155). This specimen is just a better-preserved one than that on which Natica vidali Philippi (1887, p. 85, pl. 10, fig. 17), also from Santa Cruz, was based. Philippi's Chilean specimens referred to Natica obtecta (from the Navidad Formation in central Chile, Miocene) have a taller and narrower shell with a thinner callus, especially the parietal callus. Since $N$. vidali and N. obtecta from Santa Cruz are different from the specimens of $N$. obtecta from Navidad, the specific name obtecta should be used for the Chilean taxon. Fleming (1972, p. 393, fig. 6d-6g, 11e) described and illustrated specimens collected in the Neogene deposits of Chiloé Island, in central Chile. He identified these specimens as a new species that he compared to Glossaulax obtecta, although referring it to Neverita Risso, 1826, as the massive callus shows no sign of the groove typical of Glossaulax. While we agree with such a generic placement, we have found no material on the Atlantic side of South America that could be included in Neverita. 
Ihering (1897) included a number of specimens from several localities along the coast of Santa Cruz in Natica solida Sowerby. However, as discussed by Griffin and Nielsen (2008), this material is referable to Glossaulax secundum. Ortmann described Natica darwini from Santa Cruz (Ortmann, 1902, p. 189, pl. 33, fig. 4), but the specimen he illustrated clearly belongs in Glossaulax secundum, even if the groove in the callus is not obvious in the figure, possibly because of weathering. Ortmann compared his specimen with Natica interna Say, 1824, from the Atlantic Plain in North America, stating that it could be separated from the Patagonian species by the presence of a spiral rib within the umbilicus, a feature missing in his material. Precisely this feature appears constantly in Polinices santacruzensis $(=$ Polinices darwini) and is always missing in Glossaulax secundum, which lacks the umbilical ridge.

Polinices pyrotheriana Ihering, 1907, was based on a series of specimens from Camarones, included in beds equivalent in age and facies to the Monte León Formation further South. Ihering's material includes very large specimens with severely worn shells. The shell along the suture is usually missing; a fact that makes the shell seem to be taller than it really is (see Fig. 14.5, 14.6). Unfortunately, Ihering illustrated one of the paratypes, which is also very incomplete and missing the umbilical callus entirely. At a later date (Ihering 1914, p. 85, pl. 3, fig 13) Ihering again mentioned this species in the text saying that plate 3 figure 13 were of a specimen with a preserved callus (presumably the type). However, the figure was never printed. The type specimen, a shell measuring $38 \mathrm{~mm}$ high, was not located in the collection. Also not found were the additional small paratypes mentioned by Ihering (1914, p. 85).

Neverita (Glossaulax) groeberi Brunet (1995, p. 39, pl. 4, fig 2) and Neverita (Glossaulax) keideli Brunet (1995, p. 40, pl. 4, fig. 3) are synonyms, as already stated by Martínez Chiappara et al. (1998), who believed that they could not determine whether they belonged in Glossaulax or not. However, the characteristic groove at the base of the umbilical callus leaves no doubts as to the correct generic placement of this species. It is clear that both of Brunet's names are junior synonyms of Glossaulax secundum, since no character allows separating these species.

Genus DARWINICES new genus

Type species.—Darwinices claudiae n. sp.; designated herein; Paleocene of Patagonia.

Species included.-Polynices australis d'Orbigny, 1842; Uber finlayi Marwick, 1924; Darwinices claudiae n. sp.

Diagnosis.-Polinices-like naticid with thick callus completely covering umbilicus; callus surface clearly convex; edges welldefined but flush with shell surface; parietal callus lacking transverse grooves; abapical end of callus sharply turning to meet thickened inner lip; angle of aperture to the coiling axis high.

Etymology. - Combination of Darwin (Charles) and Polinices; gender masculine.

Occurrence.-Late Cretaceous-Paleocene, New Zealand and southern South America.

Remarks.- Species included in Darwinices n. gen. show some similarity to Polinella Marwick, 1931 (type species, Uber obstructus Marwick, 1924, Miocene/Pliocene from several localities in New Zealand), where they have been traditionally placed. However, the type species of Polinella clearly shows two prominent diverging grooves on the parietal callus that defines Polinices. This groove has been used as a valid character to separate Polinices from other naticids, and therefore, the species included herein in Darwinices cannot be referred to it as the groove is missing in all available specimens. This was already noted by Beu and Maxwell (1990, p. 81) for Polinices (Polinella) finlayi Finlay and Marwick, 1937, from the Wangaloan
(Paleocene) of New Zealand. However, because they thought one evolved into the other they did not separate the species lacking transverse grooves from those with conspicuous grooves such as the type species of Polinella. A character further distinguishing Darwinices n. gen. is the high angle of the aperture plane to the coiling axis.

Another superficially similar genus used for several southern South American naticids is Magnatica Marwick, 1924 (type species, Polinices planispirus Suter), represented by Magnatica subsolida (Sowerby, 1846) and known to occur in the Miocene Navidad Formation in Central Chile. While the generic placement of Sowerby's species may be questionable, it does not appear similar to our specimens of Darwinices claudiae n. sp., which lack the open umbilicus and inner ridge or limb, nor to other naticids from the Cenozoic exposed along the Atlantic coast of Patagonia.

\section{DARWINICES ClaUdiae new species}

Figure 16.1-16.12

1994 Polinices (Polinella) cf. P. finlayi (Marwick, 1924); Griffin AND HünICKEN, p. 262, fig. 4.2, 4.3.

Diagnosis.-Thick callus completely covering umbilicus; callus surface clearly convex; edges well-defined but flush with shell surface; parietal callus lacking transverse grooves; abapical end of callus sharply turning to meet thickened inner lip; angle of aperture to the coiling axis high.

Description.- Shell medium-sized (up to $\sim 31 \mathrm{~mm}$ high), ovate in form; spire low, ranging from 0.15 of total height in young specimens to 0.25 in adults; shell thin, reaching up to $0.8 \mathrm{~mm}$ thick at mid-apertural lip; last whorl greatly inflated, evenly rounded; sutures adpressed; last whorl covering more than threequarters of previous whorl; shell smooth, with very subtly marked incremental growth lines; aperture semicircular, inclined $\sim 25^{\circ}$ from coiling axis; parietal callus thick, spreading abaperturally over umbilicus, which therefore is completely covered; surface of callus convex, pad-like, edges clearly defined but not sharply separated from shell surface; anterior lip slightly thickened.

Etymology.- Named after Claudia Griffin, for her patience and understanding over the years.

Types.-Holotype, MLP-25860; paratypes, COR-PZ-2164, one specimen from Sierra Dorotea. COR-PZ-2226, one specimen from Sierra Dorotea (H1). COR-PZ-2228, one specimen from Sierra Dorotea (q2), San José. COR-PZ-2259, one specimen from Sierra Dorotea (P-2, n). COR-PZ-2260, 23 specimens (H-72, ñ). COR-PZ-2261, one specimen (H-72, ñ). COR-PZ-2262, one specimen from Sierra Dorotea (H-72, ̃̃). COR-PZ-2263, one specimen from Sierra Dorotea (H72, ñ). COR-PZ-2264, one specimen from Sierra Dorotea (H-72, ñ). COR-PZ-2265, two specimens from Sierra Dorotea (E4-5, n). COR-PZ-2266, one specimen from Sierra Dorotea (E1, ñ). MLP-25864, four specimens from Sierra Dorotea, Señal Filo de la Mina. MLP25857, six specimens from Señal Filo de la Mina, Sierra Dorotea (q). MLP-25858, one specimen from Sierra Dorotea, Señal Filo de la Mina. MLP-25859, one specimen from Sierra Dorotea, Señal Filo de la Mina. MLP-25861, seven specimens from Sierra Dorotea, Señal Filo de la Mina. MLP-25862, one specimen from Sierra Dorotea, Señal Filo de la Mina. MACN-2125, three specimens from Sierra Dorotea (P2-E1, n). MACN-2126, one specimen from Zona San José (Punto 3, n), Río Turbio.

Type locality, Señal Filo de la Mina, Río Turbio, Argentina; Cerro Dorotea Formation. Additional material, CPBA-8349, six specimens from Puesto Álvarez, at Río Chico, Chubut; Salamanca Formation (Paleocene).

Occurrence.-Cerro Dorotea Formation (Paleocene).

Remarks.-Material referable to this species was mentioned as Polinices sp. by Hünicken (1955) for specimens he collected in 


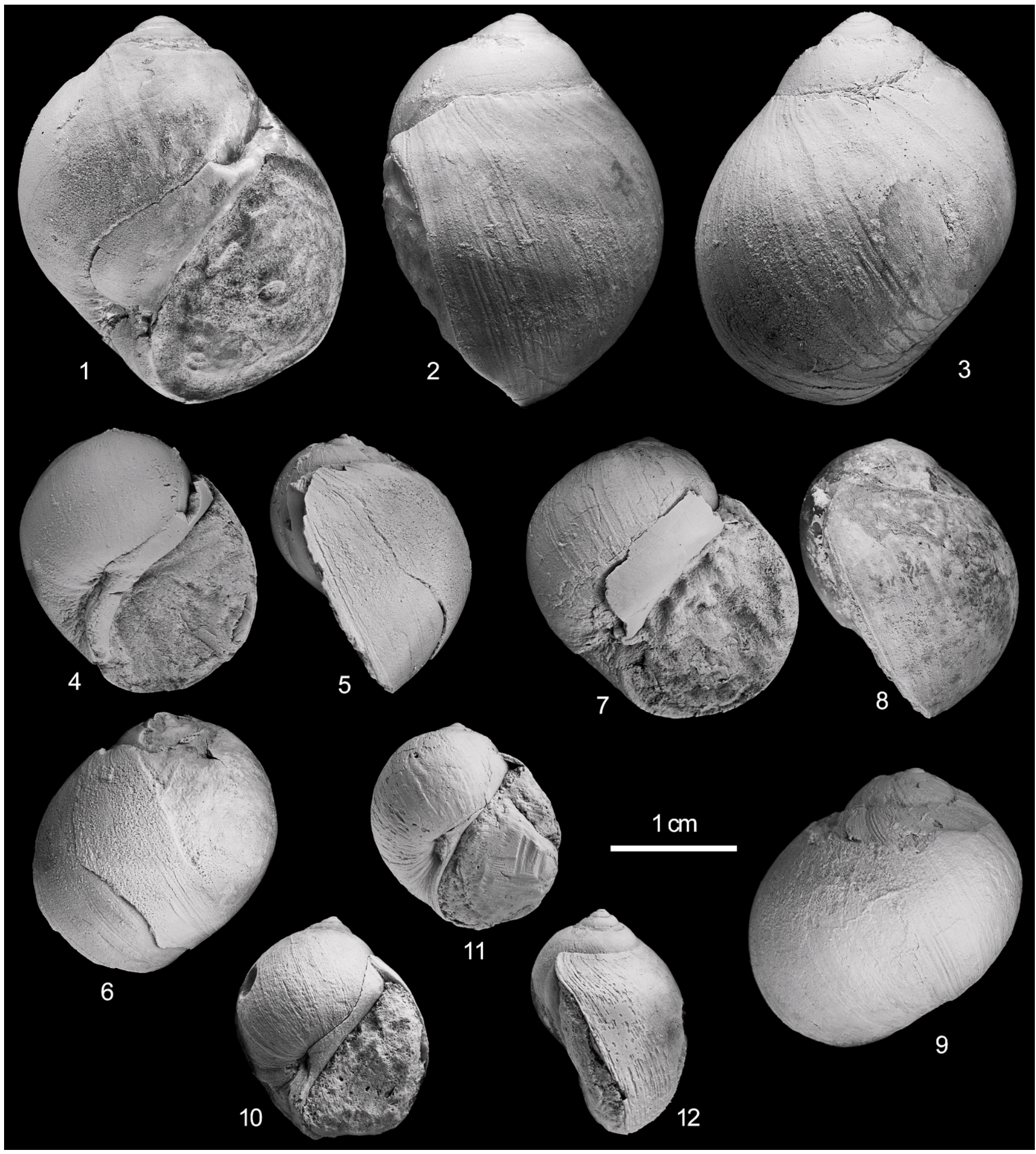

Figure 16-Darwinices claudiae n. sp. 1-3, holotype, MLP-25860; 4-6, paratype, CORPZ-2265; 7-9, MLP-25864; 10, 11, lot FCEN-8349 in apertural views; 12 , lateral views of another specimen.

the Sierra Dorotea area. It was re-identified as Polinices (Polinella) cf. P. finlayi (Marwick, 1924) by Griffin and Hünicken (1994, p. 262, fig. 4.2, 4.3). The inclusion of this taxon in Polinella was following Finlay and Marwick (1937), who described Polinices (Polinella) finlayi from Wangaloa, New Zealand. However, the generic placement of the New Zealand and
Patagonian species was not assessed then. Polinices (Polinella) finlayi is missing the grooves on the parietal callus that are present on the type species of Polinella. Thus they can not be included in the same genus. They do not fit in other genera used for NZ material either and therefore we introduce Darwinices to include the very similar Darwinices claudiae n. sp. and the New 
Zealand Darwinices finlayi. The latter is quite similar, differing mainly in the development of the callus, which seems to be slightly smaller and on its more expanded last whorl.

All six specimens collected by Masiuk (1967) at Puesto Álvarez appear to be very close to Darwinices claudiae n. sp. The two illustrated specimens show a callus very similar to that present in the species from Sierra Dorotea. The fact that they are small and probably juvenile specimens would explain the thinner callus. However, the shape of this callus and the closed umbilicus are enough, together with the spire outline and inclination of aperture, to include them in Darwinices. Whether this material is be conspecific with Darwinices claudiae n. sp. or not must wait until better specimens and a wider variety of ontogenetic stages become available.

\section{SUMMARY}

An extensive review of all available specimens in museum collections, combined with new collections made by us over the years, revealed a fairly patchy knowledge of Naticids from Cenozoic rocks in Patagonia. This is in spite of the fact that these gastropods are a substantial component of the marine faunas contained in those outcrops, most of them deposited in soft-bottom shallow shelf environments along the Atlantic coast. As for other faunas of the southern continents (Marwick, 1924), this family seems to have been generically more diversified during the Paleogene than in the Recent. No new genera appeared in southern Atlantic South American basins after the late Oligocene (represented by the San Julián Formation) except Notocochlis, appearing in the late Miocene Puerto Madryn Formation, and Tectonatica and Falsilunatia, which are known only from modern faunas. Falsilunatia was reported by Kiel and Nielsen (2010) from Miocene rocks in Chile. The geographic ranges of the fossil naticids from southern South America, however, remain somewhat obscure, because of the limited nature of the material available. These are normally molds or poor calcite replacements in which few or none of the essential shell characters are shown.

Despite the shortcomings in taxonomic identification and the problems arising from the preservation of the material, it still appears that naticids as a whole were less diverse in this part of the world than elsewhere. This is obvious in areas of the northern Hemisphere such as Japan and western North America. Marincovich (1977), who studied the western North American Cenozoic naticids, included them in 58 species, grouped in 18 genera and 14 subgenera. Majima (1989) described 47 Cenozoic species from Japan, allocated to 19 genera. In southern South America, there are comparatively fewer forms from Cenozoic stratigraphic units than in the northern hemisphere, i.e., 11 species, distributed throughout 8 genera. The reasons for this are probably environmental. In this sense, the stable shelf conditions of a passive margin offer a narrower variety of geological settings conducive to fossilization. A second reason could be a more restricted range of water depths mostly related to shallow shelf settings. At the same time, water temperatures were constrained to the cold-temperate zone, except that warmer settings have been reported for Paleogene deposits.

\section{ACKNOWLEDGMENTS}

The following persons generously gave us access to the collections under their care: M. Tanuz (Universidad de Buenos Aires, Buenos Aires), C. del Rio (Museo Argentino de Ciencias Naturales, Buenos Aires), C. Sarti (Museo Capellini, Bologna), V. Heros and P. Bouchet (Muséum National d'Histoire Naturelle), E. Ruigomez (Museo Egidio Feruglio, Trelew), A. Parras (Universidad Nacional de La Pampa, Santa Rosa), A.C.Riccardi
(Museo de La Plata, La Plata), L. Simone (Museo de Zoologia da Universidade de São Paulo, São Paulo), M. Hünicken (Universidad Nacional de Córdoba, Córdoba), J. Todd (The Natural History Museum, London). Funding was provided by the Argentine Consejo Nacional de Investigaciones Científicas y Técnicas (CONICET). Reviewers A. Beu and S. Nielsen are thanked for their helpful suggestions.

REFERENCES

Аввотт, R.T. 1974. American Seashells. Van Nostrand Reinhold Company, New York, 663 p.

Ameghino, F. 1898. Sinopsis geológico-paleontológica. Segundo Censo de la República Argentina, 1:111-225.

Anton, H. E. 1839. Verzeichniss der Conchylien welche sich in der Sammlung von Hermann Eduard Anton befinden. Halle, 110 p.

BARredA, V. 1996. Bioestratigrafía de polen y esporas dela Formación Chenque, Oligoceno tardío? Mioceno de las provincias de Chubut y Santa Cruz, Patagonia, Argentina. Ameghiniana, 33:35-56.

BARredA, V. 1997a. Palynomorph assemblage of the Chenque Formation, late Oligocene? Miocene from Golfo San Jorge Basin, Patagonia, Argentina. Part 1: Terrestrial algae, trilete and monolete spores. Ameghiniana, 34:69 80

Barreda, V. 1997b. Palynomorph assemblage of the Chenque Formation, late Oligocene? Miocene from Golfo San Jorge Basin, Patagonia, Argentina. Part 2: Gymnosperm and Colpate Pollen. Ameghiniana, 34:81-92.

BarredA, V. 1997c. Palynomorph assemblage of the Chenque Formation, late Oligocene?-Miocene from Golfo San Jorge Basin, Patagonia, Argentina. Part 3: Polycolpate and tricolpate pollen. Ameghiniana, 34:131-144.

BARredA, V. 1997d. Palynomorph assemblage of the Chenque Formation, late Oligocene? Miocene from Golfo San Jorge Basin, Patagonia, Argentina. Part 4: Polycolporate and porate pollen. Ameghiniana, 34:145-154.

Barreda, V. 1997e. Palinoestratigrafía de la Formación San Julián en el área de Playa La Mina (provincia de Santa Cruz), Oligoceno de la cuenca austral. Ameghiniana, 34:275-294.

Barreda, V. and S. Palamarczuck. 2000. Estudio palinoestratigráfico del Oligoceno tardío-Mioceno en secciones de la costa patagónica y plataforma continental argentina. INSUGEO, Serie Correlación Geológica, 14:103-138.

Bellosi, E. S. 1990. Formación Chenque: registro de la transgresión Patagoniana (Terciario Medio) de la Cuenca San Jorge, Argentina, p. 5760. In 11 Congreso Geológico Argentino Actas 2.

Bellosi, E. 1995. Paleografía y cambios ambientales de la Patagonia Central durante el Terciario Medio. Boletín de Informaciones Petrolíferas, 44:50 83.

Bertels, A. 1970. Sobre el "Piso Patagoniano" y la representación de la época del Oligoceno en Patagonia austral, República Argentina. Revista de la Asociación Geológica Argentina, 25:495-450.

Bertels, A. 1975. Bioestratigrafía del Paleógeno en la República Argentina. Revista Española de Micropaleontología, 7:429-450.

Bertels, A. 1977. Estratigrafía y micropaleontología de la Formación San Julián en su área tipo, Provincia de Santa Cruz, República Argentina. Ameghiniana, 14:233-293.

Bertels, A. 1980. Estratigrafía y foraminíferos (Protozoa) bentónicos de la Formación Monte León (Oligoceno) en su área tipo, provincia de Santa Cruz, República Argentina. 2 Congreso Argentino de Paleontología y Bioestratigrafía y 1 Congreso Latinoamericano de Paleontología, Actas 2: 213-273.

Beu, A. G. 2009. Before the ice: biogeography of Antarctic Paleogene molluscan faunas. Palaeogeography, Palaeoclimatology, Palaeoecology, 284:191-226.

Beu, A. G. and B. A. Marshall. 2011. New Cenozoic records of genera and families from New Zealand (Mollusca, Gastropoda): highlights from Phillip Maxwell's collection. New Zealand Journal of Geology and Geophysics, 54:13-34.

Beu, A. G. And P. A. Maxwell. 1990. Cenozoic mollusca of New Zealand. New Zealand Geological Survey Paleontological Bulletin, 58:1-518.

Borchert, A. 1901. Die Mollusc enfauna und das Alter der Parana-Stuffe, p. 171-245. In G. Steinmann (ed.), Beiträge zur Geologie und Paläontologie von Südamerika, IX. Neues Jahrbuch für Geologie, Mineralogie und Paläontologie 14 .

Bouchet, P. AND J. P. Rocroi. 2005. Clasification and nomenclator of gastropod families. Malacologia, 47:1-397.

Brandmayr, J. 1945. Contribución al conocimiento geológico del extremo S.S.W.del Territorio de Santa Cruz (región Cerro Cazador-Río Turbio). Boletín de Informaciones Petroleras, 22:415-443.

BRunET, R. F. J. 1995. New species of Mollusca from the Entrerriense Formation (upper Miocene) of Chubut Province, Argentina and species not 
previously reported from this formation. Part 1 - Gastropoda and Scaphopoda. Tulane Studies in Geology and Paleontology, 28:1-56.

BRUNET, R. F. J. 1997. New species of Mollusca from the Entrerriense Formation (upper Miocene) of Chubut Province, Argentina and species not previously reported from this formation. Part 2-Gastropoda. Tulane Studies in Geology and Paleontology, 30:61-98.

Bucquoy, E., P. Dautzenberg, and G. F. Dollfus. 1883. Gastropodes. Familles: Naticidae, Pyramidellidae, p. 137-196. In Les mollusques marins du Roussillon. Baillière and fils. Ed. Dollfus G., Paris.

Самасно, Н. H. 1967. Sobre las transgresiones del Cretácico Superior y Terciario de la Argentina. Revista de la Asociación Geológica Argentina, 22:253-280.

Самасно, Н. H. 1974. Bioestratigrafía de las formaciones marinas del Eoceno y Oligoceno de la Patagonia. Anales de la Academia Nacional de Ciencias Exactas, Físicas y Naturales, 26:39-57.

Casadío, S., R. M. Feldmann, and K. A. Foland. 2000. ${ }^{40} \mathrm{Ar}{ }^{39} \mathrm{Ar}$ age and oxygen isotope temperature of the Centinela Formation, southwestern Argentina: an Eocene age for crustacean-rich "Patagonian" beds. Journal of South American Earth Sciences, 13:123-132.

Casadío, S., A. M. Parras, S. A. Marenssi, and M. Griffin. 2001. Edades ${ }^{87} \mathrm{Sr} /{ }^{86} \mathrm{Sr}$ de Crassostrea? hatcheri (Ortmann)—Bivalvia, Ostreoida - en el "Patagoniano" de Santa Cruz, Argentina. Ameghiniana Suplemento Resúmenes, 38:30R.

Chiesa, J. O. and H. H. Camacho. 1995. Litoestratigrafia del Paleogeno marino en el Noroeste de la provincia de Santa Cruz, Argentina. Monografias de la Academia Nacional de Ciencias Exactas, Físicas y Naturales, 11:9-15.

Chiesa, J. O., S. G. Parma, and H. H. Camacho. 1995. Invertebrados marinos de la Formacion El Chacay (Eoceno), provincia de Santa Cruz, Argentina. Sistemática y Bioestratigrafia. Monografias de la Academia Nacional de Ciencias Exactas, Físicas y Naturales, 11:17-68.

Clark, B. L. and Durham, J. W. 1946. Eocene Faunas from the Department of Bolivar, Colombia. Geological Society of America Memoir, 16:1-126.

Codignotto, J. O. and N. Malumián. 1981. Geología de la región al norte del paralelo $4^{\circ} \mathrm{S}$ de la Isla Grande de Tierra del Fuego. Revista de la Asociación Geológica Argentina, 36:44-88.

ConRaD, T. A. 1855. Report of Mr. T. A. Conrad on the fossil shells collected in California by W. P. Blake, geologist of the expedition, under the command of Lieutenant R. S. Williamson, United States Topographical Engineers, p. 5-20. In W. Blake, Description of the Fossils and Shells Collected in California. Palaentology. House Document 129.

Cossmann, M. and A. Peyrot. 1919. Conchologie néogénique de l'Aquitaine. Tome III. Scaphopodes et gasteropodes. Actes de la Société Linnéenne de Bordeaux, 69:181-356. For dates, see Lozouet and Lesport. 1994. Sur les dates de publication de la Conchologie néogénique de l'Aquitaine par Cossmann and Peyrot (1909-1924) puis par Peyrot (1925-1935). Cossmanniana 3:9-12.

DARWIN, C. 1846. Geological observations on South America being the third part of the geology of the voyage of the Beagle during 1832-1836. Smith, Elder and Co., London, $279 \mathrm{p}$.

DEL Río, C. J. 1990a. Bioestratigrafía y cronoestratigrafía de la Formación Puerto Madryn (Mioceno Medio) provincia del Chubut, Argentina. Anales de la Academia Nacional de Ciencias Exactas Físicas y Naturales, 40:231254.

Del Río, C. J. 1990b. Composición, origen y significado de la malacofauna "Entrerriense" (Mioceno medio) de la Argentina. Anales de la Academia Nacional de Ciencias Exactas, Físicas y Naturales, 42:205-224.

DEL Río, C. J. 1991. Revisión sistemática de los bivalvos de la Formación Paraná (Mioceno medio). Provincia de Entre Ríos-Argentina. Monografías de la Academia Nacional de Ciencias Exactas, Físicas y Naturales, Buenos Aires, 7:1-93

DEL Rio, C. J. 1992. Middle Miocene Bivalves of the Puerto Madryn Formation, Valdes Peninsule, Chubut Province, Argentina. (NuculidaePectinidae). Part 1. Palaeontographica A, 225:1-57.

DeL Rio, C. J. 1994. Middle Miocene Bivalves of the Puerto Madryn Formation, Valdes Peninsule, Chubut Province, Argentina. (Lucinidae Pholadidae). Part 2. Palaeontographica A, 231:93-132.

DEL Rio, C. J. AND H. H. CAMACHO. 1998. Tertiary nuculoids and arcoids of eastern Patagonia (Argentina). Palaeontographica A, 250:47-88.

DeLL, R. K. 1990. Antarctic Mollusca with special reference to the fauna of the Ross sea. Bulletin of the Royal Society of New Zealand, 27:1-311.

Deshayes, M. G. P. 1832. Descriptions des coquilles fossiles des environs de Paris. Chez l'auteur et d'autres, Paris, vols. 1, 2; p. 814+101 pls.; for 1824 1837

Deshayes, G. P. 1839. Nouvelles espèces de mollusques, provenant des côtes de la Californie, du México, du Kamtschatka et de la Nouvelle-Zélande. Revue Zoologique par La Société Cuvierienne, 2:356-361.

Di Paola, E. and H. Marchese. 1973. Litoestratigrafía de la Formación Patagonia en el área tipo (Bajo de San Julián)-desembocadura del Río Santa
Cruz), Provincia de Santa Cruz, República Argentina. 5to Congreso Geológico Argentino, Actas 3:207-222.

DumÉRIL, A. M. C. 1806. Zoologie analytique, ou méthode naturelle de classification des animaux, rendue plus facile à l'aide de tableaux synoptiques. H. L. Perronneau, Paris, $344 \mathrm{p}$

Feruglio, E. 1935. Relaciones estratigráficas y faunísticas entre los estratos cretácicos y terciarios en la región austral del Lago Argentino y en la del Golfo San Jorge (Patagonia). Boletín de Informaciones Petroleras, 128:69 93; 130:65-100.

Feruglio, E. 1937. Paleontographia patagonica. Memorie dell'Istituto Geologico della R. Università di Padova, 9-12:1-384.

Feruglio, E. 1949. Descripción Geológica de la Patagonia. Dirección General de Y. P. F., volume II, Buenos Aires, 349 p.

Finlay, H. J. AND J. Marwick. 1937. The Wangaloan and associated molluscan faunas of Kaitangata-Green Island Subdivision. New Zealand Geological Survey Paleontological Bulletin, 15:1-140.

Fischer, P. 1880-1887. Manuel de conchyliologie et de paléontologie conchyliologique ou historie naturelle des mollusques vivants et fossils. Paris, 1369 p. (Naticidae: 764-769, 1885).

Fleming, C. A. 1972. Part II. Pliocene marine invertebrates from Chepu district, Chiloé. In Watters, W.A. and Fleming, C.A., Contributions to the geology of Chiloé Island, southern Chile. Philosophical Transactions of the Royal Society of London, Biological Sciences, 269 (853):369408

Frassinetti. D. and V. Covacevich. 1999. Invertebrados fósiles marinos de la Formación Guadal (Oligoceno Superior-Mioceno inferior) en Pampa Castillo, Región de Aisén, Chile. Boletín del Servicio Nacional de Geología y Minería, Chile 51:1-96.

Furque, G. AND H. H. CAMACHO. 1972. El Cretácico superior y Terciario de la región austral del Lago Argentino (Provincia de Santa Cruz). 4tas Jornadas Geológicas Argentinas (Mendoza 1969), Actas 3:61.

Gould, A. A. 1847. Shells collected by the U.S. Exploring Expedition under the command of Charles Wilkes. Proceedings of the Boston Society of Natural History, 2:237-239.

Gray, J. E. 1847. A list of genera of Recent Mollusca, their synonyma and types. Proceedings of the Zoological Society of London, 15:129-182.

GrifFin, M. 1991. Eocene bivalves from the Rio Turbio Formation, Southwestern Patagonia (Argentina). Journal of Paleontology, 65:119-146. Griffin, M. AND M. A. HünICKen. 1994. Late Cretaceous-early Tertiary gastropods from southwestern Patagonia, Argentina. Journal of Paleontology, 68:257-274.

Griffin, M. and G. Pastorino. 2006. Madrynomya bruneti n. gen. et n. sp. (Bivalvia: ?Modiomorphidae): a Mesozoic survivor in the Tertiary of Patagonia? Journal of Paleontology, 80:272-282.

Griffin, M. AND S. N. Nielsen. 2008. A revision of the type specimens of tertiary molluscs from Chile and Argentina described by d'Orbigny (1842), Sowerby (1846) and Hupé (1854). Journal of Systematic Palaeontology, 6: 251-316.

Guilding, L. 1834. Observations on Naticina and Dentalium, two genera of molluscous animals. Transactions of the Linnean Society of London, 17:2936.

Hanna, G. D. and L.G. Hertlein. 1943. Characteristic fossils of California. California Department of Natural Resources, Division of Mines Bulletin, 118:165-182.

Haller, M. 1978. Estratigrafía de la región al poniente de Puerto Madryn, Provincia del Chubut, República Argentina. 6to Congreso Geológico Argentino, Actas 1:285-297.

Haller, M. J. 1982. Descripción geológica de la hoja 43 h Puerto Madryn, Chubut. Boletin del Servicio de Geología Nacional, 184:1-41.

Hatcher, J. B. 1897. The Cape Fairweather beds, a new marine Tertiary horizon in southern Patagonia. The American Journal of Science, 4:327354 .

Hedley, C. 1916. Mollusca. Australasian Antarctic Expedition 1911-1914. Under the leadership of Sir Douglas Mawson, D. Sc., B.E. Scientific Reports. R. E. E. Rogers, Adelaide. Series C- Zoology and Botany, 4:1-80.

Hombron, J. B. and C. A. Jacquinot. 1854. Zoologie. Description des Mollusques coquilles et zoophytes, p. 132. In G.et J. Baudry (ed.) Voyage au Pôle Sud, et dans l'Océanie sur les corvettes l'Astrolabe et la Zélée; executé par ordre du roi pendant les années 1837-1838-1839-1840, sous le commandement de M. J. Dumont-D’Urville, Capitaine de vaisseau. E. Thunot et Ce., Paris.

HünICKEN, M. A. 1955. Depósitos Neocretácicos y Terciarios del extremo SSW de Santa Cruz (cuenca carbonífera de Río Turbio). Revista del Instituto Nacional de Investigaciones en Ciencias Naturales, Buenos Aires, Ciencias Geológicas, 4:1-161.

Hutton, F. W. 1886. The Mollusca of the Pareora and Oamaru Systems of New Zealand. Proceedings of the Linnean Society of New South Wales, series 2, 1:205-238.

ICZN. 1999. International Code of Zoological Nomenclature. The International Trust for Zoological Nomenclature, London, 306 p. 
Ihering, H. Von. 1897. Os molluscos dos terrenos terciarios da Patagonia. Revista do Museu Paulista, 2:217-382.

Inering, H. Von. 1899. Die Conchylien der patagonischen Formation. Neues Jahrbuch fur Mineralogie, Geologie und Paläontologie, p. 1-46.

Ihering, H. Von. 1907. Les Mollusques fossiles du Tertiaire et du Cretace superieur de l'Argentine. Anales del Museo Nacional de Buenos Aires, Serie III, Tomo VII:1-611.

Ihering, H. Von. 1914. Catálogo de moluscos Cretáceos e Terciarios da Argentina da colleçao do autor. Notas Preliminares da Revista do Museu Paulista, 1:1-148.

Kabat, A. R. 1991. The classification of the Naticidae (Mollusca: Gastropoda). Review and analysis of the supraspecific taxa. Bulletin of the Museum of Comparative Zoology, 152:417-449.

Kabat, A. R. 2000. Results of the Rumphius Biohistorical Expedition to Ambon (1990). Part 10. Mollusca, Gastropoda, Naticidae. Zoologische Mededelingen, 73(25):345-380.

Kase, T. and M. IshiKawa. 2003. Mystery of naticid predation history solved: Evidence from a "living fossil" species. Geology, 31:403-406.

KILBURN, R. N. 1976. A revision of the Naticidae of Southern Africa and Moçambique (Mollusca). Annals of the Natal Museum, 22(3):829-884.

Lamarck, J. B. P. A. de M. de. 1804. Suite des mémoires sur les fossils des environs de Paris. Annals du Muséum National d'Histoire Naturelle, 5:28-36.

LEACH, W. E. 1819. A list of invertebrate animals discovered by His Majesty's Ship Isabella, in a voyage to the arctic regions, corrected by ... W. E. Leach, appendix II, p. 61-64. In J. Ross, A voyage of discovery... in H.M.S. Isabella and Alexander, for the purpose of exploring Baffin's Bay and inquiring into the probability of a North-west passage, p. 1-252.

Legarreta, L. And M. A. Uliana. 1994. Asociaciones de fósiles y hiatos en el Supracretácico-Neógeno de Patagonia: una perspectiva estratigráfico secuencial. Ameghiniana, 31:257-281.

Lesta, P. And R. Ferello. 1972. Región Extraandina de Chubut y norte de Santa Cruz, p. 601-653. In A. F. Leanza (ed.), Geología Regional Argentina. Academia Nacional de Ciencias, Córdoba.

LinNAEUS, C. 1758. Systema naturae per regna tria naturae, editio decima, reformata, Stockholm 824 p.

Majima, R. 1989. Cenozoic fossil Naticidae (Mollusca: Gastropoda) in Japan. Bulletins of American Paleontology, 96:5-159.

Malumí́n, N., H. H. CAmacho, and R. Gorroño. 1979. Moluscos del Terciario inferior ("Magallanense") de la Isla Grande de Tierra del Fuego (República Argentina). Ameghiniana, 15:3-4.

Malvicini, L. And E. J. Llambías. 1974. Geología y génesis del depósito de manganeso Arroyo Verde, provincia de Chubut. $5^{\circ}$ Congreso Geológico Argentino, Actas, 2:185-202.

Manassero, M., M. Griffin, and G. Pastorino. 1997. Coquinas and shelf deposits of the San Julian Formation (Upper Eocene-Lower Oligocene) southern Patagonia, Argentina. Revista de la Asociación Geológica Argentina, 52:286-296.

Manceñido, M. O. and S. E. Damborenea. 1984. Megafauna de Invertebrados Paleozoicos y Mesozoicos. In Geología y Recursos naturales de la Provincia de Río Negro, Relatorio $9^{\circ}$ Congreso Geológico Argentino (San Carlos de Bariloche), Actas 2(5):413-465.

Marincovich, L. 1977. Cenozoic Naticidae (Mollusca: Gastropoda) of the Northeastern Pacific. Bulletins of American Paleontology, 70(294):169-494.

Martínez Chiappara, S. A., C. J. Del Rio, and V. Reichler. 1998. II. Descripciones Sistemáticas. II.1 Clase Gastropoda, p. 26-151. In C. del Río (ed.), Moluscos marinos miocenos de la Argentina y del Uruguay. Monografias de la Academia Nacional de Ciencias Exactas, Físicas y Naturales, Buenos Aires, 15:26-151.

Marwick, J. 1924. The Tertiary and Recent Naticidae and Naricidae of New Zealand. Transaction and Proceedings of the New Zealand Institute, 55: 545-579.

Marwick, J. 1931. The Tertiary Mollusca of the Gisborne District. New Zealand Geological Survey, Paleontological Bulletin, 13:1-177.

Marwick, J. 1948. Lower Pliocene Mollusca from Otahuhu, Auckland. New Zealand Geological Survey Paleontological Bulletin, 16:1-38.

Masiuk, V. 1967. Estratigrafía del Rocanense del puesto P. Alvarez, curso inferior del Río Chico, provincia del Chubut. Revista del Museo de La Plata (n.s.), 5 Paleontología 34:197-258.

Medina, F. A., H. H. Camacho, and E. C. Malagnino. 1990. Bioestratigrafía del Cretacico superior-Paleoceno marino de la Formación Lefipan. Barranca de los Perros, Río Chubut. $5^{\circ}$ Congreso Argentino de Paleontología y Bioestratigrafía. Actas, 7:137-142

Montfort, P. D. DE. 1810. Conchyliologie systématique, et classification méthodique des coquilles; offrant leurs figures, leur arrangement générique, leurs descriptions caracteristiques, leurs noms; ainsi que leur synonymie en plusieurs langues. F. Schoell, Paris, 676 p.

Murdoch, R. 1899. Description of Sigaretus? drewi, n. sp. (fossil), and Cirsonella? neozelanica, n. sp. from New Zealand; with notes on some New Zealand land Mollusca. Proceedings of the Malacological Society of London, 3:320-325.
NAÑEZ, C. 1988. Foraminíferos y bioestratigrafía del Terciario medio de Santa Cruz oriental. Revista de la Asociación Geológica Argentina, 43:493-517.

Niemeyer, H., J. Skarmeta, R. Fuenzalida, and W. Espinoza. 1984. Hojas Península de Taitao y Puerto Aisén, Región de Aisén del General Carlos Ibáñez del Campo. Servicio Nacional de Geología y Minería, Carta Geológica de Chile, $\mathrm{N}^{\circ}$ 60-61, 80 p., 1 map.

Olivero, E. B. and N. Malumián. 2008. Mesozoic-Cenozoic stratigraphy of the Fueguian Andes, Argentina. Geologica Acta, 6:5-18

Orbigny, A. D. D’ 1834-1847. Mollusques. In C. P. Bertrand (ed.), Voyage dans l'Amérique Méridionale (Le Brésil, La République Orientale de L’Uruguay, La République Argentine, La Patagonie, La République du Chili, La République de Bolivia, La République du Pérou), exécuté pendant les années 1826, 1827, 1828, 1829, 1830, 1831, 1832 et 1833,. Chez Ve. Levrault, Paris. (For correct dates of plates and pages see Sherborn, C. D., and F. J. Griffin, 1934. On the dates of publication of the Natural History Portions of Alcide d'Orbigny's 'Voyage Amérique Méridionale, see Annals and Magazines of Natural History, serie 10 13:130-134).

Orbigny, A. D'. 1852. Prodrome de Paléontologie stratigraphique universelle des animaux mollusques et rayonnés faisant suite au cours élémentaire de paléontologie et de géologie stratigraphique, Volume 3. Victor Masson, Paris, $196+190 \mathrm{p}$.

Ortmann, A. E. 1899. The fauna of the Magellanian beds of Punta Arenas, Chile. American Journal of Science, 4:427-432.

Ortmann A. E. 1900. Synopsis of the Collections of Invertebrate fossils made by the Princeton Expedition to Southern Patagonia. American Journal of Science, Fourth Series, 10:368-381.

Ortmann, A. E. 1902. Paleontology, Part II. Tertiary Invertebrates, p. 45-332. In W.B. Scott (ed.), Reports of the Princeton University Expeditions to Patagonia, 1896-1899. Vol. 4, Paleontology I part 2. J. Pierpont Morgan Publication Fund, Princeton New Jersey.

PArodiz, J. J. 1996. The taxa of fossil Mollusca introduced by Hermann von Ihering. Annals of the Carnegie Museum, 65:183-296.

Pastorino, G. 2005. Recent Naticidae (Mollusca: Gastropoda) from the Patagonian coast. The Veliger, 47:225-258.

Petersen, C. S. 1946. Estudios geológicos en el Río Chubut Medio. Boletín de la Dirección General de Minería y Geología, 59:1-137

Philippi, R. A. 1845a. Diagnosen einiger neuen Conchylien. Archiv für Naturgeschichte, 11:50-71.

PhilipPI, R. A. 1845b. Abbildungen und Beschreibungen neuer oder wenig gekannter Conchylien herausgegeben. Cassel, vol. 2 of 3, Natica, p. 41-46; from $1844-1851$

Philippi, R. A. 1887. Los Fosiles Terciarios i Cuartarios de Chile. Brockhaus, Leipzig, $256 \mathrm{p}$.

Pilsbry, H. A. 1929. Neverita reclusiana (Desh.) and its allies. The Nautilus, 42(4):09-113.

Powell, A. W. B. 1927. On a large Tonna and two other gasteropods of Australian origin. Transaction and Proceedings of the New Zealand Institute, 57:559-562.

Powell, A. W. B. 1933. New species of marine Mollusca from the subantarctic islands of New Zealand. Proceedings of the Malacological Society of London, 20:232-236.

Powell, A. W. B. 1951. Antarctic and subantarctic mollusca: Pelecypoda and Gastropoda. Discovery Reports, 26:47-196.

RÉcluZ, C. A. 1844. Descriptions of new spcies of Navicella, Neritina, Nerita, and Natica in the cabinet of H. Cuming, Esq. Proceedings of the Zoological Society of London, 11:197-214.

Reichler, V. A. 2010. Estratigrafía y paleontología del Cenozoico marino del Gran Bajo y Salinas del Gualicho, Argentina, y descripción de 17 especies nuevas. Andean Geology, 37:177-219

RigGi, J. C. 1957. Resumen geológico de la zona de los lagos Pueyrredón y Posadas, Provincia de Santa Cruz. Revista de la Asociación Geológica Argentina, 12:65-97.

Risso, A. 1826. Histoire naturelle des principales productions de l'Europe méridionale et particulièrement des celles des environs de Nice et des Alpes Maritimes, vol. 4. Levrault, Paris, 438 p.

Rochebrune, A. T. D' AND J. Mabille. 1885. Diagnoses de mollusques nouveaux, recueillis par les membres de la mission du Cap Horn et M. Lebrun, Préparateur au Muséum, chargé d'une mission à Santa-Cruz de Patagonie. Bulletin de la Société Philomathique de Paris, 7(9):100-111.

Rochebrune, A. T. D' and J. Mabille. 1889. Mollusques, p. 143-149. In Mission Scientifique du Cap Horn, 1882-1883. Gauthier-Villars et fils, Paris.

Rosenberg, G. 2009. Malacolog 4.1.1: A Database of Western Atlantic Marine Mollusca. Online database (version 4.1.1); http://www.malacolog.org/.

Rossi de García, E. 1959. Nuevos moluscos Terciarios del Arroyo Verde (Provincia de Río Negro, Argentina). Ameghiniana, 1(4):9-15.

Rossi de García, E. And R. Levy. 1977. Fauna de la Formación Arroyo Verde, Eoceno de la provincia de Río Negro, Argentina. Ameghiniana, 14(1-4) $45-52$. 
SACCO, F. 1890. I molluschi dei terreri terziarii del Piemonte e della Liguria. Part 8 (Galeodoliidae, Doliidae, Ficulidae, Naticidae). Università di Torino, Musei Zoolgia e. Anatomia Comparata, Bolletino, 5(86):21-43.

SAY, T. 1824. An account of some of the fossil shells of Maryland. Journal of the Academy of Natural Sciences of Philadelphia 4:124-155

Scasso, R. A., C. J. del Rio, J. M. Macarthur, and S. A. Martínez. 1999. Edades ${ }^{87} \mathrm{Sr} /{ }^{86} \mathrm{Sr}$ para el Entrerriense (Miocenos) de península Valdés, provincia de Chubut, Argentina. $14^{\circ}$ Congreso Geológico Argentino (Salta, 1999), Resúmenes, Acta, 1:73.

Scopoli, G. A. 1777. Introductio ad historiam naturalem, sistems gnera lapidum, plantarum et animalium hactenus detecta, caracteribus essentialibus donata, in tribus divisa, subinde ad leges naturae. Prague, $506 \mathrm{p}$.

Sedgwick, A. And R. Murchison. 1832. A sketch of the structure of the Eastern Alps. Geological Society of London, Transactions, 23(2), 301-420.

Sмiтh, J. 1839. Catalogue of recent shells in the basin of the Clyde and north coast of Ireland; and of shells from the newer Pliocene deposits in the British Isles. Wernerian Natural History Society (Edinburgh) Memoirs, 8: 89-113.

SoHL, N. F. 1960. Archeogastropoda, Mesogastropoda and stratigraphy of the Ripley, Owl Creek, and Prairie Bluff formations. United States Geological Survey Professional Paper 331A, p. 1-151.

Sowerby, G. B. I. 1846. Descriptions of Tertiary fossil shells from South America, p. 249-267. In C. Darwin, Geological Observations on South America. Smith, Elder and Co., London.

Sowerby, J. 1812-1846. The mineral Conchology of Great Britain; or coloured figures and description of those remains of testaceous animals or shells which have been preserved at various times and depths in the earth B. Meredith, London.

Sowerby, J. 1837. Mineral-Conchologie Grossbrittaniens, von James Sowerby; deutsche Bearbeitung, herausgegeben von Hercules Nicolet, durchgesehen von Dr. Agassiz. H. Nicolet, Neuchâtel, 52 p.
Stewart, R. B. 1927. Gabb's California fossil type gastropods. Proceedings of the Academy of Natural Sciences of Philadelphia, 78:287-447.

Stilwell, J. D. And W. J. Zinsmeister. 1992. Molluscan systematics and biostratigraphy: lower Tertiary La Meseta Formation, Seymour Island, Antarctic Peninsula. American Geophysical Union, Antarctic Research Series, 55:1-192.

StoliczKa, F. 1868. Cretaceous fauna of southern India. Volume II. The Gastropoda of the Cretaceous rocks of southern India. Palæontologica Indica (Memoirs of the Geological Survey of India), part 7-10, p. 285-498. Suter, H. 1907. Descriptions of some Tertiary shells from New Zealand. Proceedings of the Malacological Society of London, 7:207-210.

Troschel, F. H. 1852. Verzeichniss der durch Herrn Dr. v. Tschudi in Peru gesammelten Conchylien. Archiv für Naturgeschichte, 18:151-208.

Turner, F. E. 1938. Stratigraphy and Mollusca of the Eocene of Western Oregon. Geological Society of America Special Paper 10, p. 1-130.

Uliana, M. A. And L. Legarreta. 1999. Jurásico y Cretácico de la cuenca del Golfo San Jorge. In R. Caminos (ed.), Geología Argentina. Subsecretaría de Minería de la Nación, Servicio Geológico Minero Argentino, Instituto de Geología y Recursos Minerales, Anales, 29:496-510.

Wilckens, O. 1905. Die Lamellibranchiaten, Gastropoden etc. der Oberen Kreide Südpatagoniens. Berichte der Naturforschenden Gesellschaft Freiburg, 15:97-166.

Wolff, H. And V. Schenk. 1972. Zur Taxonomie, Phylogenie und Paläogeographie von Ampullina (Pseudamaura) (Naticidae, Gastropoda) in der Kreide. Neues Jahrbuch für Geologie und Paläontologie, Abhandlungen, 140(2):232-254.

Woodring, W. P. 1928. Contributions to the geology and palaeontology of the West Indies. Miocene molluscs from Bowden, Jamaica. Part II. Gastropoda and Discussion of Results. Carnegie Institute of Washington Publication, 385:1-564.

ACCePTed 12 DeCember 2012 